\title{
Anticancer potential of bioactive peptides from animal sources (Review)
}

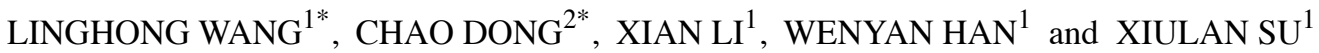 \\ ${ }^{1}$ Clinical Medicine Research Center of the Affiliated Hospital, Inner Mongolia Medical University; \\ ${ }^{2}$ College of Basic Medicine of Inner Mongolia Medical University, Huimin, Hohhot, Inner Mongolia 010050, P.R. China
}

Received October 10, 2016; Accepted April 10, 2017

DOI: $10.3892 /$ or.2017.5778

\begin{abstract}
Cancer is the most common cause of human death worldwide. Conventional anticancer therapies, including chemotherapy and radiation, are associated with severe side effects and toxicities as well as low specificity. Peptides are rapidly being developed as potential anticancer agents that specifically target cancer cells and are less toxic to normal tissues, thus making them a better alternative for the prevention and management of cancer. Recent research has focused on anticancer peptides from natural animal sources, such as terrestrial mammals, marine animals, amphibians, and animal venoms. However, the mode of action by which bioactive peptides inhibit the proliferation of cancer cells remains unclear. In this review, we present the animal sources from which bioactive peptides with anticancer activity are derived and discuss multiple proposed mechanisms by which these peptides exert cytotoxic effects against cancer cells.
\end{abstract}

\section{Contents}

1. Introduction

2. Animal sources of bioactive peptides with anticancer activity

Correspondence to: Professor Xiulan Su, Clinical Medicine Research Center of the Affiliated Hospital, Inner Mongolia Medical University, 1 Tongdao North Street, Huimin, Hohhot, Inner Mongolia 010050, P.R. China

E-mail: xlsu@hotmail.com

*Contributed equally

Abbreviations: ACE, angiotensin-converting enzyme; ACPB-3, anticancer bioactive peptide-3; SALF, shrimp anti-lipopolysaccharide factor; KLH, keyhole limpet hemocyanin; CTX, chlorotoxin; LAAOs, L-amino acid oxidases; Bl-LAAO, Bothrops leucurus; Ltc2a, latarcins 2a; Pen-2, penaeidin-2; mPTP, mitochondrial permeability transition pore; MOMP, mitochondrial outer membrane permeabilization; OPA1, optic atrophy1; PHB1, prohibitin 1; DAMPs, death-associated molecular patterns

Key words: bioactive peptides, anticancer activity, animal sources
3. Mechanisms of action of bioactive peptides underlying their anticancer effects

4. Summary and perspective

\section{Introduction}

Although the rates of death due to cancer have been continuously declining for the past 2 decades in developed nations, cancer remains a major public health threat in many parts of the world (1). The incidence of cancer in the developing world is currently increasing. Specifically, $55 \%$ of new cases arise in developing nations, a figure that could reach $60 \%$ by 2020 and $70 \%$ by 2050 . Worldwide, cancer also causes a substantial burden of economic cost and human suffering; the cost associated with cancer cases worldwide was approximately US $\$ 1.16$ trillion in 2010, the equivalent of $>2 \%$ of the total global gross domestic product. Nevertheless, this high figure is a lower bound and does not include the substantial longer-term costs to families and caregivers (2).

The current gold standard of care for cancer is a combination of surgery, radiation therapy, and chemotherapy (3-5). However, traditional methods are associated with drawbacks, such as a lack of screening tests for early diagnosis and a lack of tumor-specific drug delivery systems. Moreover, most classical anticancer drugs cannot differentiate between cancerous and normal cells, thus leading to systemic toxicity and adverse side effects. Selective and more efficient new drugs are urgently needed to address this problem. In this context, bioactive peptides are increasingly being considered as good drug candidates for cancer therapeutic applications. A growing body of peptides from natural animal sources has been demonstrated to possess physiological functions, such as immunomodulatory (6), antimicrobial (7), antihypertensive (8), antithrombotic (9), anticancer (10), antioxidative (11), and cholesterol-lowering activities (12). However, this review focuses on bioactive peptides from animal sources that may specifically target cancer cells and could consequently serve as anticancer agents that are less toxic to normal tissues. In addition, as shown in Fig. 1, bioactive peptides usually consist of 2-50 amino acid residues $\left(\sim 10^{2}-10^{3} \mathrm{Da}\right)$. Thus, they easily traverse or disrupt the cell membrane and result in apoptosis or necrosis. Therefore, the study and modification of bioactive peptides with anticancer activity will offer new opportunities for cancer prevention and treatment. 
The objectives of this study are to 1) review the current understanding of anticancer bioactive peptides derived from different animal sources and 2) summarize the mechanisms of action by which bioactive peptides affect cancer cells. In addition, this review highlights the potential applications of natural animal source-derived peptides as pharmaceutical candidates in the auxiliary therapy of cancer.

\section{Animal sources of bioactive peptides with anticancer activity}

Terrestrial mammals and by-products. Although bioactive peptides with anticancer activity from terrestrial mammals are not well documented, one report has described four bovine meat-derived peptides that inhibit angiotensin-converting enzyme (ACE) and also exhibit anti-proliferative activity (13). Specifically, this study has demonstrated the cytotoxic effect of four peptides: GFHI, DFHING, FHG, and GLSDGEWQ. GFHI has been found to exhibit the most potent cytotoxic effect on the human breast cancer cell line (MCF-7) and to decrease the viability of a stomach adenocarcinoma cell line (AGS) in a dose-dependent manner, whereas GLSDGEWQ significantly inhibits the proliferation of AGS cells.

The group of $\mathrm{Su}$ identified the novel anticancer bioactive peptide-3 (ACPB-3) $(14,15)$, which was isolated from goat spleens or livers. This peptide has been found to exhibit anticancer activity against a human gastric cancer cell line (BGC-823) and gastric cancer stem cells (GCSCs) in vitro and in vivo. Moreover, it significantly inhibits the growth of BGC-823 and CD44+ cells in a dose-dependent manner, suppressing the proliferation of spheroid cell colonies and inhibiting their clone-forming capacity. In vivo, ACBP-3 alone or in combination with cisplatin suppresses xenograft tumor growth, and this peptide enhances the chemotherapy tolerance of mice by reducing the toxicity of the treatment during long-term experiments $(15,16)$. The Su group also investigated the anticancer activity of ACBPs in a human colorectal tumor cell line (HCT116) in vitro and in vivo (17). Specifically, treatment with ACBPs significantly inhibits HCT116 cell growth, enhances UV-induced apoptosis, increases the expression levels of PARP and p53, and decreases the expression of Mcl-1. Moreover, ACBPs markedly inhibit human colorectal tumor growth in a xenograft nude mouse model and induce changes in the expression levels of PARP, P53, and $\mathrm{Mcl}-1$, consistently with the changes observed in vitro, without producing apparent changes in body weight. These studies indicate that ACBPs inhibit human colorectal tumor cell growth and induce apoptosis by modulating the PARPp53-Mcl-1 signaling pathway.

Milk and dairy products contain numerous components that exhibit a wide variety of physiological and functional activities. Moreover, bioactive peptides have been considered to be the important bioactive components of milk and dairy products, and they have been identified within the amino acid sequences of milk proteins. The intrinsic bioactivities of peptides encrypted in major milk proteins are latent until they are released and activated in three ways: 1) digestive enzymemediated hydrolysis, 2) hydrolysis by proteins from proteolytic microorganisms, and 3) digestion by proteolytic enzymes derived from microorganisms or plants (18).
A number of studies have reported the anticancer effects of milk protein-derived peptides on various cancer cells. Roy et al (19) found that bovine skim milk digested with cellfree extract from the yeast Saccharomyces cerevisiae inhibits the proliferation of a human leukemia cell line (HL-60). Meisel and FitzGerald reported the anticancer activity of casein fraction-derived caseinophosphopeptides (CPPs) (20), which inhibit cancer cell growth and stimulate the activity of immunocompetent cells and neonatal intestinal cells. Moreover, the bacterial hydrolysis of casein by commercial yogurt starter cultures yields bioactive peptides that influence colon cell kinetics in vitro (21), and a yogurt fraction obtained by membrane dialysis has been found to have an anti-proliferative effect on Coca-2 and IEC-6 mammalian intestinal cells (22).

Lactoferrin is an $80-\mathrm{kDa}$ iron-binding glycoprotein that belongs to the transferrin family and has a variety of biological functions, including antibacterial, antiviral, anticancer, anti-inflammatory, and immunomodulatory activities (23). Moreover, lactoferricin is a cationic peptide generated by the acid-pepsin hydrolysis of lactoferrin and exhibits a range of biological activities, including cytotoxic activity against various microorganisms (24,25) and cancer cells (26-28). The major anticancer mechanisms of lactoferrin and lactoferricin include cell cycle arrest, apoptosis, anti-angiogenesis effects, anti-metastasis effects, immune modulation and necrosis (28). Thus, the aforementioned studies suggest that milk proteins are not only a nutritious part of a normal daily diet but also have potential for the prevention and/or management of cancer.

Marine animals. Bioactive peptide compounds from marine animals have been reported to have a broad range of bioactive properties (29-31). An increasing number of recent studies have focused on bioactive peptides with potential anticancer activity isolated from various marine animals, such as sponges, tunicates, ascidians, mollusks, fish, and other marine organisms (32-35).

Fish. Fish is a popular seafood item worldwide and have been identified as a source of bioactive peptides with potential anticancer activities. Selected fish-derived bioactive peptides with potential anticancer activity are listed in Table I.

The potential anti-proliferative activity of hydrolysate of a by-product from dark tuna muscle has been examined in MCF-7 cells (36). Specifically, peptide fractions with molecular weights ranging from 400-1400 Da exhibit the strongest anti-proliferative activity. Two anti-proliferative peptides, LPHVLTPEAGAT from papain hydrolysate and PTAEGVYMVT from Protease XXIII, have been identified in those fractions. Guha and others (33) have reported a $100-\mathrm{kDa}$ Thomsen-Friedenreich disaccharide (TFD)-containing glycopeptide, named TFD-100, purified from the Pacific cod. TFD-100 binds to galactin-3 ( $\beta$-galactoside-binding lectin) and inhibits the adhesion of androgen-independent prostate cancer cells (PC3) to endothelial cells, angiogenesis, and gal3-induced T-cell apoptosis.

Lee and colleagues $(37,38)$ have reported that peptides isolated from anchovy sauce induce apoptosis in a human lymphoma cell line (U937) by increasing the activities of caspase- 3 and caspase- 8 activity, and the authors have purified 


\section{Increasing Molecular Weight (MW)}

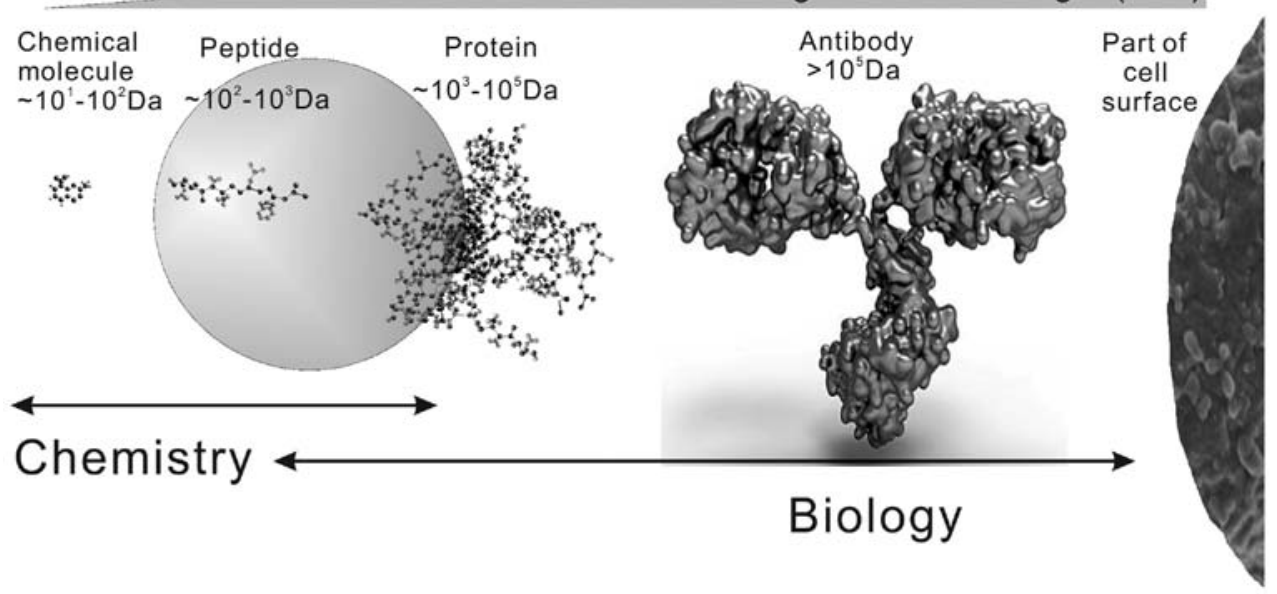

Figure 1. Left to right shows the sizes and molecular weight (MW) increasing from chemical molecular to biology cell. The anticancer peptides mentioned in this review mainly focus on circle area.

Table I. Fish sources of selected bioactive peptides with potential anticancer activity.

\begin{tabular}{|c|c|c|c|}
\hline Fish & Peptide name & Anticancer activity & References \\
\hline Anchovy & & Induce apoptosis in a U937 cells & $(37,38)$ \\
\hline Blue whiting & & Antiproliferative activity on MCF-7/6 and MDA-MB-231 & (39) \\
\hline Cod & TFD100 & $\begin{array}{l}\text { Inhibited adhesion of PC3 to endothelial cells, angiogenesis, } \\
\text { and gal3-induced T-cell apoptosis }\end{array}$ & $(33)$ \\
\hline Cod & & Antiproliferative activity on MCF-7/6 and MDA-MB-231 & (39) \\
\hline Grouper & Epinecidin-1 & Inhibited the proliferation of U937 cells & $(42)$ \\
\hline Plaice & & Antiproliferative activity on MCF-7/6 and MDA-MB-231 & (39) \\
\hline Red sea bream & Chrysophsin-1 & $\begin{array}{l}\text { Antitumor activities and modulates the inflammatory response } \\
\text { in RAW264.7 cells }\end{array}$ & $(43)$ \\
\hline Red sea flatfish & Pardaxin & Antitumor activity toward $\mathrm{MN}-11$ cells in vitro and in vivo & $(44)$ \\
\hline Salmon & & Antiproliferative activity on MCF-7/6 and MDA-MB-231 & $(39)$ \\
\hline Tilapia & $\begin{array}{l}\text { TH1-5, TH2-2, } \\
\text { and TH2-3 }\end{array}$ & $\begin{array}{l}\text { TH1-5 and TH2-3 exhibited anticancer activity against HeLa } \\
\text { cells and HT-1080 cells, respectively }\end{array}$ & $(40,41)$ \\
\hline Tuna & & Antiproliferative on MCF-7 cells & $(36)$ \\
\hline
\end{tabular}

a 440.9-Da hydrophobic peptide. Moreover, the anti-proliferative activities of protein hydrolysates from different fish species, including blue whiting, cod, plaice and salmon, have been investigated in vitro in two human breast cancer cell lines (MCF-7/6 and MDA-MB-231) (39). Hepcidin consists of three hepcidin-like antimicrobial peptides (named TH1-5, TH2-2, and TH2-3) and has been isolated from tilapia. Of these peptides, TH1-5 and TH2-3 exhibit anticancer activity against epithelial carcinoma cells (HeLa) and human fibrosarcoma cells (HT-1080), respectively $(40,41)$.

In addition, several studies have shown that peptides from different fish sources exert clear anticancer activity against various carcinoma cell lines, such as human hepatocellular liver carcinoma cells (HepG2), U937 cells, HeLa cells and murine fibrosarcoma cells (MN-11) (42-44). These data suggest the potential of fish as a valuable source of anticancer peptides for incorporation into functional foods.

Shrimp. Wilson-Sanchez et al (45) have demonstrated the antimutagenic and anti-proliferative activities of lipidic extracts from white shrimp. Specifically, the lipid fraction of white shrimp contains compounds that have been found to reduce the mutagenicity of aflatoxin B1 and the proliferation of a B-cell lymphoma cell line. Moreover, shrimp anti-lipopolysaccharide factor (SALF), an antimicrobial peptide from black tiger shrimp $(46,47)$, enhances the anticancer activity of cisplatin in vitro and inhibits HeLa cell growth in nude mice. These peptides also exhibit significant anticancer activity in human colon and liver cancer cell lines, even when they are isolated from shrimp waste (48). 
Ascidians. Bioactive peptides with anticancer activity have also been identified in tunicates and ascidians. Didemnins are a family of cytotoxic peptides isolated from tunicates (49), and acyclic depsipeptide, Didemnin B, has been widely studied because of its high anticancer potential $(50,51)$. Didemnin B inhibits proliferation by inhibiting the synthesis of RNA, DNA and protein (51,52). Aplidine, a cyclic depsipeptide isolated from the Mediterranean tunicate Aplidium albicans, has antiangiogenic activity both in vitro and in vivo (53), and aplidine was first identified on the basis of its enhanced cytotoxicity against different tumor cell lines, such as breast, melanoma, lung and ovarian cancer cell lines, and its lower myelotoxicity relative to Didemnin B (53-57). Tamandarins A and B are also cytotoxic depsipeptides from a marine ascidian of the family Didemnidae, and the effects of these peptides have been evaluated in various human cancer cell lines $(58,59)$. Mollamide and Trunkamide A obtained from ascidians both are cytotoxic to different human tumor cell lines (58).

A novel polypeptide (CS5931) with anticancer activity has been identified by the group of Lin $(60,61)$, who have demonstrated that CS5931 extracted from Ciona savignyi induces apoptosis via a mitochondria-mediated pathway in human colorectal carcinoma cells (HCT-8) in a dose- and timedependent manner. CS5931 is strongly anti-angiogenic in vitro and in vivo, and this effect may be mediated by vascular endothelial growth factor (VEGF) and matrix metalloproteinases (MMPs). These studies indicate that CS5931 has the potential to be developed as a novel angiogenesis inhibitor for the treatment of cancer.

Sponges. Marine sponges are an abundant source of bioactive peptides with anticancer potential. In recent years, most researchers have focused on bioactive cyclic peptides and depsipeptides with highly unique structures that contain a wide variety of unusual amino acids and other building blocks (62-64).

Seven cytotoxic cyclic peptides (Callyaerins A-F and $\mathrm{H}$ ) isolated from the Indonesian sponge (Callyspongia aerizusa) are cytotoxic to murine lymphoma cells (L5178Y), HeLa cells, and pheochromocytoma tumor cells (PC12) (63). Furthermore, reniochalistatins A-E, five cyclic peptides (including four heptapeptides and one octapeptide) from the marine sponge Reniochalina stalagmitis, and the cyclic octapeptide reniochalistatin E are cytotoxic to different tumor cell lines (65). Rolloamides A and B are cytotoxic cyclic heptapeptides isolated from the Caribbean sponge (Eurypon laughlini), androlloamide $\mathrm{A}$ has been found to significantly suppress the growth of a panel of histologically diverse cancer cells (66). A new peptide, gombamide A, isolated from the Korean sponge Clathria gombawuiensis is weakly cytotoxic to human lung carcinoma (A549) and myelogenous leukemia (K562) cell lines and moderately inhibits $\mathrm{Na}^{+} / \mathrm{K}^{+}$-ATPase.

Jaspamide is a cyclic depsipeptide isolated from sponges of the genus Jaspis and Hemiastrella (32) and induces apoptosis in HL-60 $(67,68)$ and Jurkat T cells $(69)$. Two jaspamide derivatives, jaspamide 2 and 3 , have been isolated from an Indonesian sponge (Jaspis splendens), and low concentrations of these peptides inhibit the growth of L5178Y cells in vitro (70). Nine cyclodepsipeptides from the sponge Homophymia sp., homophymines B-E and A1-E1, have exhibited very potent cytotoxic activity with $\mathrm{IC}_{50}$ values in the $\mathrm{nM}$ range against a panel of human cancer cell lines (71). Recently, two cyclic depsipeptides isolated from a Madagascan sponge (Homophymia lamellosa), pipecolidepsins A and B (64), have been found to exhibit cytotoxic activity against human lung, colon, and breast cancer cells $(64,72)$.

Geodiamolide $\mathrm{H}$, a depsipeptide isolated from a Brazilian sponge (Geodia corticostylifera), inhibits the migration and invasion of breast cancer cells by modifying the actin cytoskeleton (73).

Three lipodepsipeptides (Lipodiscamides A-C) isolated from the marine sponge Discodermia kiiensis are moderately cytotoxic to murine leukemia cells (P-388) and HeLa cells (74). Moreover, taumycin A, another lipodepsipeptide from a Madagascan sponge (Fascaplysinopsis sp.), has been found to inhibit the growth of a human leukemic cell line (75).

Callyptide A, a newly identified cytotoxic peptide from the Red Sea marine sponge (Callyspongia), has been found to inhibit the growth of different cancer cell lines, including MDA-MB-231 cells, A549 cells and human colorectal adenocarcinoma cells (HT-29), with GI $_{50}$ values of $29,18.5$ and $30 \mu \mathrm{M}$, respectively (31). Smenamides $\mathrm{A}$ and $\mathrm{B}$ are two isomerichybrid peptide/polyketide compounds isolated from a Caribbean sponge (Smenospongia aurea) that contain a dolapyrrolidinone unit and show potent cytotoxic activity at nanomolar levels against lung cancer Calu-1 cells (76).

Mollusks. Several studies have reported that mollusks, such as shellfish, sea slugs, and sea hares, are rich sources of bioactive peptides that exhibit anticancer activity. Wang et al have isolated oligopeptide-enriched hydrolysates from oysters by using protease (77) and have shown that these hydrolysates markedly and dose-dependently inhibits sarcoma-S180 tumor cell growth in BALB/c mice. Furthermore, Cheong et al (78) and Kim et al (79) have reported two novel anticancer peptides isolated from oysters and mussels, respectively. The sequences of these two anticancer peptides differ, but both exhibit clearly superior cytotoxic activity and effectively induce cell death in prostate, breast and lung cancer cells.

Keyhole limpet hemocyanin (KLH) is a high-molecularweight copper-containing protein found in the hemolymph of the marine mollusk Megathura crenulata (80). This extracellular respiratory protein has many bioactive properties (81-83), including immunostimulatory, antitumor, and antimicrobial activity. Riggs et al and McFadden et al $(84,85)$ have shown that KLH from the giant keyhole limpet significantly inhibits the growth of different cancer cells in vitro, including estrogendependent breast cancer cells (MCF-7), estrogen-independent breast cancer cells (ZR75-1), pancreatic cancer cells (PANC-1), prostate cancer cells (DU145), and Barrett's esophageal adenocarcinoma cells (SEG-1 and BIC-1). Moreover, a cytokine analysis has revealed that KLH directly affects the production of cellular inflammatory and pro-apoptotic mediators. Furthermore, KLH increases early and late apoptotic activity in MCF-7 cells, whereas it reduces late apoptotic activity in the ZR75-1 cells. In contrast, KLH does not affect the early or late apoptotic activity of PANC-1 cells. These results suggest that KLH directly inhibits the growth of human breast and pancreatic cancer in vitro by modulating apoptotic and nonapoptotic mechanisms (86). 
Dolastatins are a family of cytotoxic peptides isolated from the mollusk Dolabella auricularia. In this family, the linear pentapeptide Dolastatin 10 and the depsipeptide Dolastatin 15 have been reported to exhibit promising anti-proliferative activity $(87,88)$. In recent years, synthetic dolastatin 10 analogs have been widely used in anticarcinogen drug development (89-91). These studies have provided strong evidence showing that Dolastatin 10 analogs effectively inhibit cell growth by dampening microtubule dynamics, inducing apoptotic cell death, and inhibiting tumor growth.

Aurilide is a small cyclodepsipeptide isolated from Dolabella auricularia that induces apoptosis in human cancer cells at low concentrations (92). Specifically, aurilide selectively binds to prohibitin 1 (PHB1) in the mitochondria, activating the proteolytic processing of dynamin-like GTPase optic atrophy 1 (OPA1) and resulting in mitochondria-induced apoptosis. The mechanism of aurilide cytotoxicity suggests that PHB1 is an apoptosis-regulating protein amenable to modulation by small molecules. Thus, aurilide may serve as a small-molecule tool for studies of mitochondria-induced apoptosis $(93,94)$.

Kahalalides are a family of peptides isolated from Elysia rufescens. Among them, Kahalalide F is regarded as an important anticancer candidate for tumor therapeutics, owing to its high cytotoxicity (95-97). However, the mechanism of action of Kahalalide F is not well understood, and Kahalalide F has been observed to disturb lysosomal function and to potentially result in intracellular acidification and cell death. Thus, this peptide may effectively combat cancer cells exhibiting high lysosomal activity, such as prostate and cervical cancer cells (98). Moreover, Janmaat and others have demonstrated that ErbB3 and the downstream phosphatidylinositol 3-kinase (PI3K)-Akt signaling pathway are important determinants of the cytotoxic activity of Kahalalide $\mathrm{F}$ in vitro (99).

Finally, Keenamide A is a cytotoxic cyclic hexapeptide isolated from the notaspidean mollusk Pleurobranchus forskalii that significantly inhibits the proliferation of P-388, A-549, and HT-29 cells (100).

\section{Amphibians}

Frog and toad skin secretions. Skin secretions from amphibians (e.g., frogs and toads) contain a wide range of compounds with biological activity and have garnered attention because of their potential for drug development (101). In addition, the Chinese have traditionally administered secretions from frog skin and toad parotid glands for medicinal purposes since ancient times (102). Hundreds of such peptides have been identified since the discovery of the first antimicrobial peptide from this source (103), and some naturally occurring amphibian skin peptides and analogs are selectively cytotoxic to tumor cells and are promising anticancer agents (101). The primary structures of selected bioactive peptides with anticancer properties isolated from frog skin secretions are listed in Table II.

Alyteserin-2a, obtained from the midwife toad (Alytes obstetricans), exhibits relatively weak antimicrobial and cytotoxic activities (104). However, analogs of alyteserin-2a are potently cytotoxic to A549 cells, human hepatocarcinoma cells (HepG2), MDA-MB-231 cells, and HT-29 cells (105).

Conlon et al (106) have reported two bioactive peptides, ascaphin- 8 and peptide XT-7, isolated from the skin secretions of Ascaphus truei and Silurana tropicalis. These peptides are highly cytotoxic to HepG2 cells. Moreover, the analogs of these peptides are more cytotoxic to HepG2 cells than the natural bioactive peptides.

Several aurein peptides exhibiting anticancer activity have been reported by Rozek et al (107), who extracted Aureins 1, 2 and 3.1 from the green and golden bell frog (Litoria aureus) and the southern bell frog (Litoria raniformis).

van Zoggel et al (108) have reported that two bioactive peptides of the dermaseptin family (dermaseptin B2 and B3) isolated from skin secretions of the South American tree frog (Phyllomedusa bicolor) exhibit antitumor and angiostatic properties. Specifically, the authors demonstrated that these two peptides inhibit both the proliferation of a human prostatic adenocarcinoma cell line (PC-3) by $>90 \%$ in vitro and the differentiation of bovine aortic endothelial cells. Most recently, Shi et al (109) have identified two novel members of the dermaseptin antimicrobial peptide family, dermaseptinPD-1 and dermaseptin-PD-2, in the skins/skin secretions of the phyllomedusine leaf frog (Pachymedusa dacnicolor). These two peptides have been found to modulate the growth of PC-3 cells, a human non-small cell lung cancer cell line (H157), and a human neuronal glioblastoma cell line (U251MG) with low hemolytic activity. Moreover, both dermaseptins are less cytotoxic to normal human cell lines (109). Dermaseptin L1 and phylloseptin L1, isolated from the skin secretions of the lemur leaf frog (Agalychnis lemur), are both cytotoxic to HepG2 cells (110). Dermaseptin L1 is cytolytic to HepG2 cells but not human erythrocytes, whereas phylloseptin L1 is approximately equipotent against both HepG2 cells and erythrocytes. In addition, the novel phylloseptin-PBa, isolated from the skin secretion of the purple-sided leaf frog (Phyllomedusa baltea), has been found to inhibit the proliferation of several human cancer cell lines: lung cancer cells (H460), PC-3 cells and a neurospongioma cell line (U251MG). However, it is less active in a normal human micro-vessel endothelial cell line (HMEC-1) (111).

Magainin-2, isolated from Xenopus laevis, and its analog magainin $\mathrm{G}$, exhibits tumoricidal activity against human small cell lung cancer cell lines (112) and bladder cancer cell lines (113). Another modified magainin-2 peptide, MSI-238, is markedly more potent than the parent peptide, displaying a significant cytotoxic effect on A549 cells in vitro and P-388 cells, ascites (S180), and a spontaneous ovarian tumor in vivo (114). In addition, several studies have reported other magainin-2 analogs that are cytotoxic to U937 (115) and HeLa cells (116). Li et al (117) have isolated a small antibacterial peptide, Xenopus laevis antibacterial peptide-P1 (XLAsp-P1), from the skin of Xenopus laevis by using reverse-phase highperformance liquid chromatography, and this peptide strongly and dose-dependently inhibits breast cancer cells.

Moreover, pentadactylin from Leptodactylus labyrinthicus reduces the viability of murine melanoma (B16F10) cells in a dose-dependent manner without significantly affecting normal human fibroblast cells (118). Specifically, pentadactylin alters cell morphology, disrupts the membrane, fragments DNA, arrests cells in the $\mathrm{S}$ phase of the cell cycle, and alters mitochondrial membrane potential, thus suggesting that this peptide affects B16F10 cells via an apoptosis pathway.

Attoub and colleagues have extracted the frog-derived peptide Hymenochirin-1B, which is highly cytotoxic to 
Table II. Primary structures of selected bioactive peptides with anticancer properties from frog skin secretions.

\begin{tabular}{|c|c|c|c|c|c|}
\hline Species & Family & Peptide name & Primary structure & Activity & References \\
\hline $\begin{array}{l}\text { Midwife toad } \\
\text { (Alytes obstetricans) }\end{array}$ & Alytidae & Alyteserin-2 & ILGKLLSTAAGLLSNL & Cytotoxicity on A549 cells & $(105)$ \\
\hline $\begin{array}{l}\text { Tailed frog } \\
\text { (Ascaphus truei) }\end{array}$ & Ascaphidae & Ascaphin-8 & $\begin{array}{l}\text { GFKDLLKGAAKALV } \\
\text { KTVLF }\end{array}$ & Cytotoxicity on HepG2 cells & $(106)$ \\
\hline $\begin{array}{l}\text { Green and golden bell frog } \\
\text { (Litoria aureus) }\end{array}$ & Hylidae & Aurein 1.2 & GLFDIIKKIAESF & Anticancer activity & $(107)$ \\
\hline $\begin{array}{l}\text { Green and golden bell frog } \\
\text { (Litoria aureus) }\end{array}$ & Hylidae & Aurein 3.1 & GLFDIVKKIAGHIAGSI & Anticancer activity & $(107)$ \\
\hline $\begin{array}{l}\text { Giant monkey frog } \\
\text { (Phyllomedusa bicolor) }\end{array}$ & Hylidae & Dermaseptin B2 & $\begin{array}{l}\text { GLWSKIKEVGKEAAKAA } \\
\text { AKAAGKAALGAVSEAV }\end{array}$ & $\begin{array}{l}\text { Inhibited the proliferation of } \\
\text { PC- } 3 \text { cells }\end{array}$ & $(108)$ \\
\hline $\begin{array}{l}\text { Giant monkey frog } \\
\text { (Phyllomedusa bicolor) }\end{array}$ & Hylidae & Dermaseptin B3 & $\begin{array}{l}\text { ALWKNMLKGIGKLAG } \\
\text { QAALGAVKTLVGAE }\end{array}$ & $\begin{array}{l}\text { Inhibited the proliferation of } \\
\text { PC- } 3 \text { cells }\end{array}$ & $(108)$ \\
\hline $\begin{array}{l}\text { Phyllomedusine leaf frog } \\
\text { (Pachymedusa dacnicolor) }\end{array}$ & Hylidae & Dermaseptin-PD-1 & $\begin{array}{l}\text { GMWSKIKETAMAAAK } \\
\text { EAAKAAGKTISDMIKQ }\end{array}$ & $\begin{array}{l}\text { Inhibited growth of PC- } 3 \text { cells, } \\
\text { H157 cells, U251MG cells }\end{array}$ & $(109)$ \\
\hline $\begin{array}{l}\text { Phyllomedusine leaf frog } \\
\text { (Pachymedusa dacnicolor) }\end{array}$ & Hylidae & Dermaseptin-PD-2 & $\begin{array}{l}\text { GMWSKIKNAGKAAAKA } \\
\text { AAKAAGKAALDAVSEAI }\end{array}$ & $\begin{array}{l}\text { Inhibited growth of PC- } 3 \text { cells, } \\
\text { H157 cells, U251MG cells }\end{array}$ & $(109)$ \\
\hline $\begin{array}{l}\text { Lemur leaf frog } \\
\text { (Agalychnis lemur) }\end{array}$ & Hylidae & Dermaseptin L1 & $\begin{array}{l}\text { GLWSKIKEAAKAAGKAA } \\
\text { LNAVTGLVNQGDQPS }\end{array}$ & $\begin{array}{l}\text { Cytotoxic activity against } \\
\text { HepG } 2 \text { cells }\end{array}$ & $(110)$ \\
\hline $\begin{array}{l}\text { Lemur leaf frog } \\
\text { (Agalychnis lemur) }\end{array}$ & Hylidae & Phylloseptin L1 & LLGMIPLAISAISALSKL & $\begin{array}{l}\text { Cytotoxic activity against } \\
\text { HepG } 2 \text { cells }\end{array}$ & $(110)$ \\
\hline $\begin{array}{l}\text { Peruvian purple-sided leaf frog } \\
\text { (Phyllomedusa baltea) }\end{array}$ & Hylidae & Phylloseptin-PBa & $\begin{array}{l}\text { MAFLKKSLFLVLF(F/L)GL } \\
\text { VSLSIC }\end{array}$ & $\begin{array}{l}\text { Anti-proliferative activity } \\
\text { against } \mathrm{H} 460 \text { cells, PC } 3 \text { cells } \\
\text { and } \mathrm{t} \mathrm{U} 251 \mathrm{MG} \text { cells }\end{array}$ & $(111)$ \\
\hline $\begin{array}{l}\text { Pepper frog } \\
\text { (Leptodactylus labyrinthicus) }\end{array}$ & Leptodactylidae & Pentadactylin & $\begin{array}{l}\text { GLLDTLKGAAKNVVGSL } \\
\text { ASKVMEKL }\end{array}$ & $\begin{array}{l}\text { Cytotoxic activity on B16F10 } \\
\text { cells without high specificity }\end{array}$ & $(118)$ \\
\hline $\begin{array}{l}\text { Congo dwarf clawed frog } \\
\text { (Hymenochirus boettgeri) }\end{array}$ & Pipidae & Hymenochirin-1B & $\begin{array}{l}\text { KLSPETKDNLKKVLK } \\
\text { GAIKGAIVAKMV }\end{array}$ & $\begin{array}{l}\text { Cytotoxic activity against A549 } \\
\text { cells, MDA-MB- } 231 \text { cells, } \\
\text { HT- } 29 \text { cells, and HepG } 2 \text { cells }\end{array}$ & $(119)$ \\
\hline $\begin{array}{l}\text { South African clawed frog } \\
\text { (Xenopus laevis) }\end{array}$ & Pipidae & Magainin-2 & $\begin{array}{l}\text { GIGKFLHSAKKFGKAFV } \\
\text { GEIMNS }\end{array}$ & $\begin{array}{l}\text { Tumoricidal activity against } \\
\text { human small cell lung cancer cell } \\
\text { lines and bladder cancer cell lines }\end{array}$ & $(112,113)$ \\
\hline $\begin{array}{l}\text { South African clawed frog } \\
\text { (Xenopus laevis) }\end{array}$ & Pipidae & XLAsp-P1 & DEDDD & $\begin{array}{l}\text { Inhibition activity against } \\
\text { breast cancer cell }\end{array}$ & $(117)$ \\
\hline $\begin{array}{l}\text { Tropical clawed frog } \\
\text { (Silurana tropicalis) }\end{array}$ & Pipidae & Peptide XT-7 & GLLGPLLKIAAKVGSNLL & Cytotoxicity on HepG2 cells & $(106)$ \\
\hline $\begin{array}{l}\text { Chiricahua leopard frog } \\
\text { (Lithobates chiricahuensis) }\end{array}$ & Ranidae & Esculentin-2CHa & $\begin{array}{l}\text { GFSSIFRGVAKFASKGLGK } \\
\text { DLAKLGVDLVACKISKQC }\end{array}$ & $\begin{array}{l}\text { Cytotoxic activity against } \\
\text { A549 cells }\end{array}$ & $(120)$ \\
\hline
\end{tabular}

A549 cells, MDA-MB-231 cells, HT-29 cells, and HepG2 cells (119). Moreover, the (D9K) analog is most potent against all four cell lines (up to 6-fold increase in cytotoxicity), but its hemolytic activity is also increased. In contrast, the (D9k) and (E6k, D9k) analogs retain relatively high cytotoxicity against tumor cells but are less hemolytic than the parent peptide (119). Moreover, the same group has identified another frog-derived peptide, Esculentin-2Cha, which is highly cytotoxic to A549 cells (120). In this study, the authors found that two analogs both remain cytotoxic to A549 cells but have completely contrary effects on hemolytic activity.

Crocodile and turtle. Crocodilians are minimally affected by infections or death from microorganisms, and cancer has not been observed in crocodiles to date, thus suggesting that these animals have a strong innate immune system that protects against undesirable cells. These characteristics make crocodilians a good choice for the study of anticancer 
agents. Previous studies have indicated that alligator serum, including leukocyte extract, has a broad spectrum of activity against bacteria, viruses and amoeba via the complement system (121-124). Pata et al have reported four novel antibacterial peptides isolated from the white blood cell extract of the Siamese crocodile, Leucrocin I-IV, which exhibit strong antibacterial activity against Staphylococcus epidermidis, Salmonella typhi and Vibrio cholera (125). On the basis of this work, Yaraksa et al designed and synthesized the novel antibacterial peptides L-and D-NY15 by using the peptide Leucrocin I as a sequence template, and these peptides exhibit potent antibacterial activity without any toxicity to mammalian cells at their bacteriolytic concentrations (126).

Additionally, Patathananone and colleagues (127) have investigated the anticancer activity of crocodile leukocyte extracts. Specifically, they have shown that the percentage of viable HeLa cells significantly decreases in a dose- and time-dependent manner after treatment with white blood cell extracts. They have further demonstrated that the anticancer compounds from crocodile leukocyte extracts induces apoptosis in HeLa cells via both caspase-dependent and caspase-independent pathways (127).

Recently, Theansungnoen et al (128) have indicated that the cationic antimicrobial peptides KT2, RT2 and RP9 from Crocodylus siamensis leukocyte extract exhibit anticancer activities against human cervical cancer cells but do not affect non-cancer cells.

He et al (129) have reported antitumor peptides derived from the enzymatic hydrolysates of the Chinese three-striped box turtle (Cuora trifasciata). Two fractions, T1 and T2, inhibit HepG2 and MCF-7 cancer cells, and three peptides have been identified in these fractions: RGVKGPR (T1-1), KLGPKGPR (T1-2), and SSPGPPVH (T2-1). T2-1 was found to be a novel peptide that had not been listed in any database and exhibits the most potent inhibition toward MCF-7 cancer cells.

Animal venoms. Animal venoms and toxins consist of a complex cocktail of proteins and peptides and are enriched in approximately 100-1,000 biologically active peptides. Thus, they have been used as a therapeutic resource in folk and traditional medicine for centuries, and they remain largely unexplored resource for the discovery of novel bioactive peptides.

Scorpion venom. Among venomous animals, scorpions, the oldest arthropods on Earth, possess a venom apparatus connected to the telson, which is used to inject the venom. Scorpions can be phylogenetically divided into 18 distinct families consisting of $>1,500$ species (130), and scorpion venom has been used in traditional medicine for many centuries (131). However, possibly $<1 \%$ of all venoms from known scorpion species have been studied in detail (132).

Scorpion venom is a source of peptidyl neurotoxins, which are used as tools to study different ion channels, such as the $\mathrm{Na}^{+}, \mathrm{K}^{+}, \mathrm{Ca}^{+}$, and $\mathrm{Cl}^{-}$ion channels. Chlorotoxin (CTX) is a small neurotoxin of 36 amino acids that was isolated in 1993 from the venom of the Israeli scorpion Leiurus quinquestriatus (133). Initially, CTX was used as a pharmacological tool to characterize chloride channels. However, CTX cannot kill cancer cells on its own, despite its ability to inhibit tumor invasion. CTX can target cancer cells, including glioma, melanoma, small cell lung carcinoma, neuroblastoma and medulloblastoma cells. These properties make CTX a very attractive peptide for targeted cancer therapy or imaging (134). Moreover, CTX has been demonstrated to deeply diffuse into tumors, unlike other targeting agents, such as antibodies $(135,136)$. Therefore, CTX should limit changes in cell shape in the setting of glioma, thereby hampering the ability of the tumor to invade tissue. This mechanism corroborates the reported anti-invasive effects of CTX on glioma cells and the inhibition of metastasis (137-140). Recently, Guo et al identified two linear $\alpha$-helical peptides in the venom of the Brazilian yellow scorpion, TsAP-1 and TsAP-2 (Tityus serrulatus antimicrobial peptide) and demonstrated their anti-proliferative effects on human cancer cells, namely a human squamous carcinoma cell line (NCI-H157) and a human lung adenocarcinoma cell line (NCI-H838). Moreover, TsAP-2 is three times more active than TsAP-1 against an androgen-independent prostate adenocarcinoma cell line (PC-3), MCF-7 cells, and a human glioblastoma cell line (U251) (141). Ali et al have isolated a new chlorotoxin-like peptide (Bs-Tx7) from the venom of the common yellow scorpion (Buthus sindicus). This peptide inhibits thechlorotoxin (ClTx) and CFTR channels (GaTx1) by $66 \%$ and $82 \%$, respectively, and an amino acid sequence analysis of Bs-Tx7 has identified a scissile peptide bond (i.e., Gly-Ile) for human MMP2, whose activity is increased in malignant tumors. This finding suggests that Bs-Tx7 inhibits tumor proliferation by decreasing MMP2 activity (142).

Spider venom. Spider venom contains versatile proteins and peptides including enzymes (such as proteases, hyaluronidases, and phospholipases), neurotoxins (most have disulfide-rich peptides affecting ion channels), and cytolytic peptides (143). Latarcin 2a (Ltc2a), a short cationic linear $\alpha$-helical peptide isolated from the venom of a spider (Lachesana tarabaevi), is cytotoxic against human erythroleukemia K562 cells. This cytotoxicity is primarily related to plasma membrane destabilization; Ltc2a induces the formation of small (approximately $2.0 \mathrm{~nm}$ ) membrane pores on the plasma membrane of K562 cells and subsequent blebbing, swelling and eventual cell death (144). Spider venom-derived peptide lycosin-1 strongly inhibits cancer cell growth in vitro and effectively suppresses tumor growth in vivo by interfering with cell signaling pathways via the attenuation of the activities of key proteins (145).

Bee and wasp venom. Venom from bees and wasps is now being studied to design and develop new therapeutic drugs from the proteins and peptides in venom (146). Melittin (MEL), an amphiphilic peptide (26 amino acid residues) isolated from the honey bee Apis mellifera, is the most studied and well-known bee venom-derived peptide (147). MEL inhibits different cancer cells in vitro, including astrocytoma, leukemic, lung tumor, ovarian carcinoma, squamous carcinoma, glioma, hepatocellular carcinoma, osteosarcoma, prostate cancer and renal cancer cells (148-152). Although it is cytotoxic to a broad spectrum of tumor cells, this peptide is also toxic to normal cells. Thus, MEL must be accurately delivered to a targeted area to optimize results $(153,154)$.

Similarly to MEL, mastoparan is a well-studied 14-amino acid amphipathic and cationic peptide obtained from Vespula 
lewisii venom that has shown antitumor activity in vitro (146). It also needs to be precisely delivered to avoid side effects, as described by Yamada and colleagues (155). Moreover, several structural modifications may improve the pharmacodynamic parameters of chimeric mitoparan in vivo $(146,156)$.

Snake venom. The therapeutic use of snake venoms is frequently studied by scientists. Most venoms are a complex mixture of several proteins, peptides, enzymes, toxins and non-protein components. Bioactive peptides from snake venoms have significantly contributed to the treatment of many medical conditions, and some peptides and enzymes from snake venom may specifically target cancer cell membranes, affecting the migration and proliferation of these cells $(157,158)$.

Crotamine, a polypeptide of 42 amino acids first isolated from South American rattle snake venom, was the first venom-derived peptide classified as a natural cell-penetrating and antimicrobial peptide with pronounced antifungal activity (158). Pereira et al have investigated the toxicity of this peptide toward cancer cells in vitro and in vivo in a mouse model of melanoma; they have tested the viability of B16-F10 (murine melanoma cells), SK-Mel-28 (human melanoma cells), and Mia PaCa-2 (human pancreatic carcinoma cells) at crotamine concentrations of $1-5 \mu \mathrm{g} / \mathrm{ml}$. Noteworthy, a final crotamine concentration of $5 \mu \mathrm{g} / \mathrm{ml}$ is lethal to B16-F10, MiaPaCa-2, and SK-Mel-28 cells but not to normal cells $(159,160)$.

Cathelicidin-BF (BF-30) is a cathelicidin-like polypeptide consisting of 30 amino acids and a natural antibacterial peptide extracted from the venom of the snake Bungarus fasciatus. BF-30 inhibits B16F10 cell proliferation in vitro in a doseand time-dependent manner. Moreover, BF-30 significantly suppresses melanoma growth in B16F10 tumor-bearing mice without inducing losses in body weight (161). Naumann et al have isolated and purified L-amino acid oxidases (LAAOs) from Bothrops leucurus (B1-LAAO) and have reported the biochemical features of B1-LAAO associated with its effect on platelet function and cytotoxicity. Bl-LAAO is cytotoxic to the stomach cancer cell line MKN-45, the adenocarcinoma cell line HUTU, the colorectal cancer cell line RKO and the human fibroblast cell line LL-24. Specifically, this enzyme releases sufficient amounts of $\mathrm{H}_{2} \mathrm{O}_{2}$ into the culture medium to induce apoptosis in cells in a doseand time-dependent manner (162).

\section{Mechanisms of action of bioactive peptides underlying their anticancer effects}

Since anticancer peptides non-specifically destroy the plasma membrane, they show therapeutic potential for tumors that are not responsive to conventional pharmaceutical therapy. Although some major mechanisms of action have already been outlined, the exact mechanism by which bioactive peptides kill cancerous cells remains controversial. In general, the anticancer effect of bioactive peptides may be mediated either by membranolytic or by non-membranolytic mechanisms (163)

Membrane-related mechanisms. The plasma membrane of cells is a very effective selectively permeable barrier. Although this phospholipid bilayer is essential for cell survival and function, many studies have indicated that natural antimicrobial peptides kill cancer cells by disrupting the cellular membrane $(128,164,165)$. Specifically, peptides target negatively charged membrane components in the membrane, such as phosphatidylserine (PS), sialic acid or heparan sulfate. In fact, the exposure of the negatively charged lipid PS on the outer leaflet of the cancer cell membrane is a key difference between cancerous and non-cancerous cells, which are overall neutrally charged, owing to zwitterionic phosphatidylcholine and sphingomyelin $(166,167)$.

Papo et al have found that a short host defense-like peptide selectively targets cancer cells, primarily by binding to PS exposed on the surfaces of cells, thus resulting in cytoplasmic membrane depolarization and cell death. Consequently, peptide-lipid interaction is a critical step for the effective disruption of the cell membrane (168). Latarcins 2a (Ltc2a), a peptide extracted from the venom of the spider Lachesana tarabaevi, is cytotoxic to human erythroleukemia K562 cells. Specifically, the peptide affects the plasma membrane of cells and induces membrane blebbing, swelling and eventual cell death, as observed with fluorescently labeled Ltc2a. Moreover, the peptide binds to the outer membrane leaflet of K562 cells, consequently triggering PS externalization. Cytotoxicity is due to the formation of membrane pores (approximately $3.7 \mathrm{~nm}$ ), which are more permeable to anionic than cationic molecules, and the redistribution of PS toward the outer leaflet of the membrane has been detected in the cells. Of note, the peptide does not activate apoptosis (144). Pore formation is accompanied by self-assisted Ltc2a internalization and accumulation in mitochondria, mitochondrial inactivation and apoptosisindependent phosphatidylserine externalization (169).

The mechanism underlying the membranolytic activity of each peptide depends on the characteristics of the bioactive peptide and those of the target membrane, which in turn modulate peptide selectivity and toxicity. Bioactive peptide-induced membrane disruption can occur via different modes: pore formation in the lipid (barrel-stave and toroidal pore models), the thinning of the membrane bilayer, membrane dissolution (carpet model), or lipid-peptide domain formation $(166,170)$.

The barrel-stave model describes the lateral insertion and diffusion of peptides through the lipid bilayer, where they arrange into helices and create barrel/stave-like channels that span the membrane (171). As shown in Fig. 2, cecropins (from moths) (172), pardaxin (from the Red Sea sole) (173), magainins (from frogs) (174) and melittin (from the European honey bee) $(175,176)$ induce cell lysis via pore formation and follow this model.

According to the toroidal model, peptide molecules maintain a predominantly parallel orientation to the membrane, and a water core forms the center of the pore, with the bioactive peptides and lipid head groups forming the wall of the pore (177). As shown in Fig. 2, Magainins (from frogs) (174), melittin (from bee venom) $(175,176)$, and protegrins (from porcine leukocytes) (178) all follow this mode of action.

Another classical mechanism of action is described by the carpet model. In this model, peptides do not form pores but bind parallel to the membrane surface, forming a 'carpet' in association with other peptide monomers. The bilayers are disrupted and form micelles, destroying the membrane 


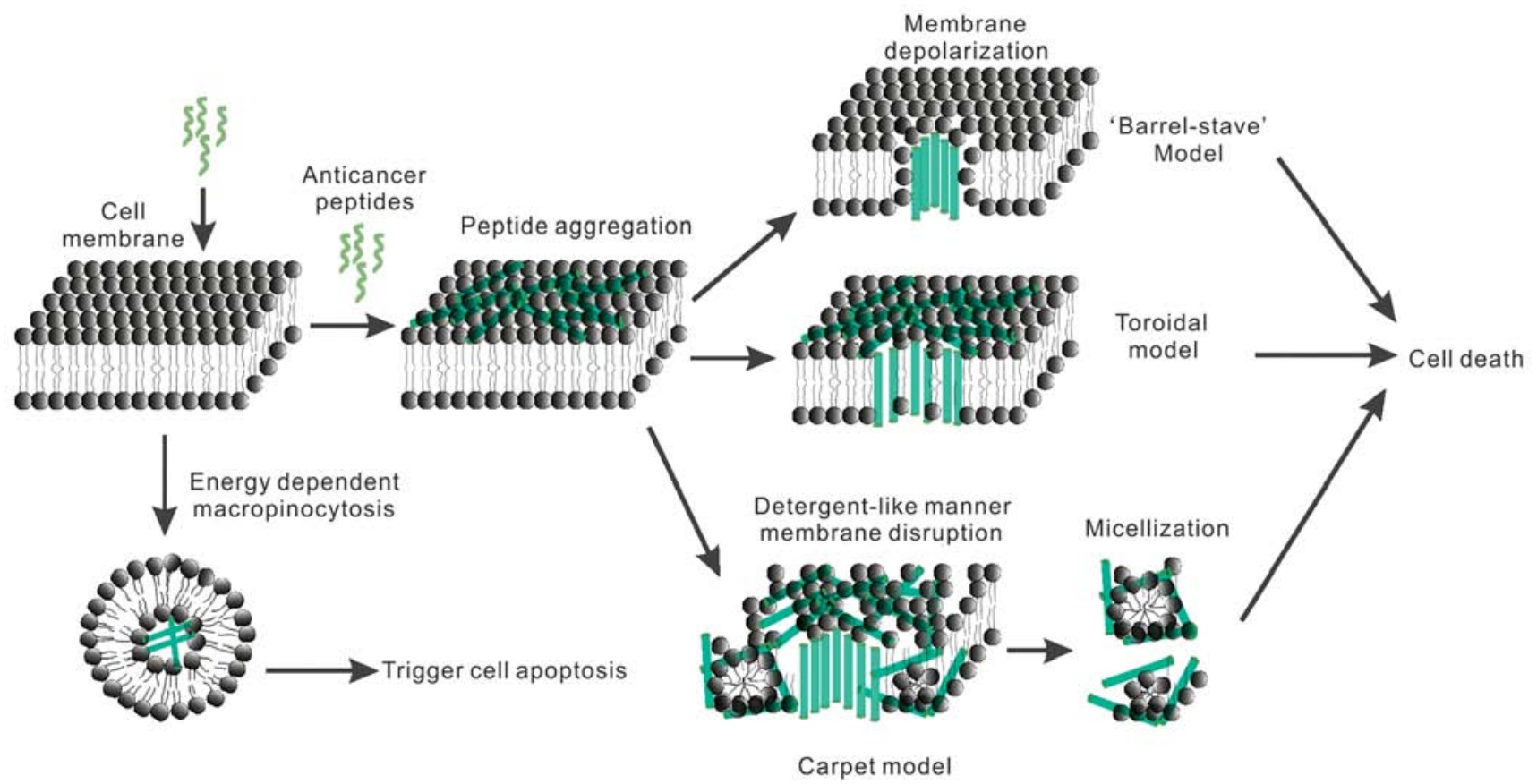

Figure 2. Schematic illustration of cell entry mechanisms of anticancer pepetides.

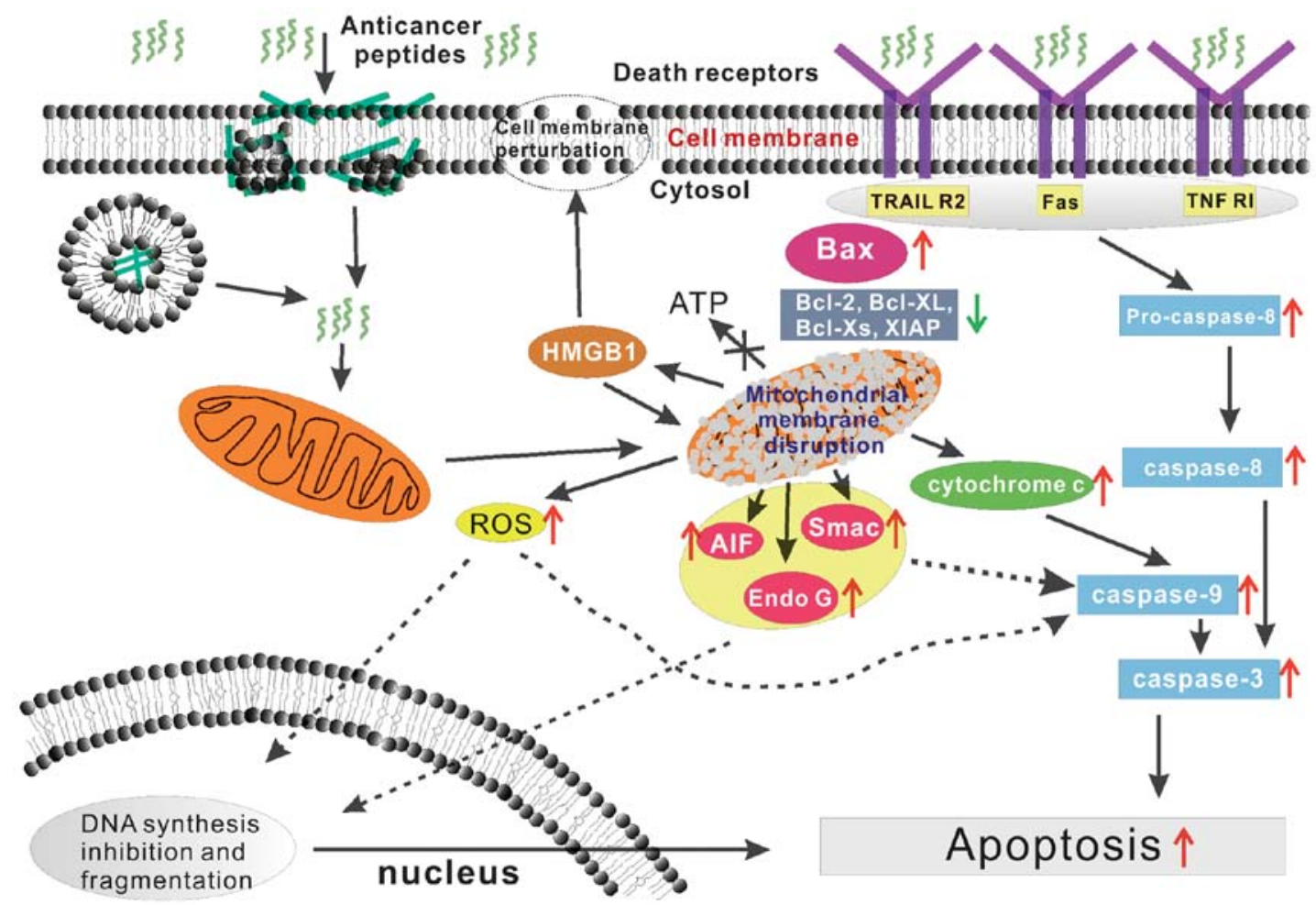

Figure 3. Mechanisms of action of anticancer peptides via mitochondrial-dependent pathways and death receptor-induced pathways.

structure in a detergent-like manner at a certain peptide concentration showed in Fig. 2 (179,180).

Since peptides and lipids are highly dynamic, Bechinger (181) has proposed the 'Soft Membranes Adapt and Respond, also Transiently' (SMART) model, which describes the interaction between peptides and the membrane from a global dynamic viewpoint: peptides and lipids change and mutually adapt their conformations, and membrane penetration and morphology are described in detail on a local and a global level. As a result, peptides and lipids can form a wide variety of supramolecular assemblies. In contrast, charged amphipathic sequences tend to remain intercalated at the membrane interface, where they cause pronounced disruptions of phospholipid fatty acyl packing. With increasing local or global concentrations, 
the peptides result in transient membrane opening, rupture and ultimately lysis. Therefore, the same peptide sequence can result in a variety of these responses, depending on the peptide-to-lipid ratio, lipid composition and environmental factors (temperature, buffer composition and ionic strength).

Mitochondrial membrane disruption and mitochondrialdependent apoptosis. In addition to inducing cell death by disrupting the plasma membrane, some anticancer peptides induce apoptosis via the mitochondrial pathway (182), and mitochondrial membrane disruption-induced apoptosis plays a crucial role in both carcinogenesis and cancer therapy as showed in Fig. 3 (183). Hence, understanding this pathway is very important for bioactive peptide applications. The early opening of the mitochondrial permeability transition pore (mPTP) in the inner mitochondrial membrane (IMM) is a key event in primary necrosis. These events interrupt ATP synthesis and result in the influx of large amounts of water and small solutes to the matrix along their electrochemical gradients, which results in severe osmotic swelling of mitochondria and ultimately in necrotic cell death. Furthermore, mitochondrial outer membrane permeabilization (MOMP), allows the release of pro-apoptotic factors, including cytochrome c (Cyt c), which activate caspases, apoptosis-inducing factor (AIF), second mitochondria-derived activator of caspase (Smac) and endonucleases showed in Fig. 3 (184-186).

Penaeidin-2 (Pen-2) is an important antimicrobial peptide derived from the Pacific white shrimp, and recombinant pen-2 (rPen-2) has been found to strongly inhibit the growth of ACHN and A498 kidney cancer cells in a time- and dosedependent manner. This effect is less pronounced in renal tubular epithelial HK-2 cells. Two different phenomena, apoptosis and lysis, have been observed, thus suggesting that rPen-2 caused membrane disruption and apoptosis of tumor cells (187). The antimicrobial peptides NRC-03 and NRC-07 from the Atlantic flounder target and damage mitochondria and consequently induce a loss of transmembrane potential in breast cancer cells. These peptides also induce the production of reactive oxygen species (ROS) and cell death via mitochondrial-dependent apoptosis or the inhibition of DNA synthesis showed in Fig. $3(188,189)$.

Recently, Patathananone et al have reported that leukocyte extract from the crocodile (C. siamensis) is cytotoxic to human cervical cancer cells in a protein concentrationdependent manner. Specifically, the mitochondrial membrane potential (DWm) of HeLa cells rapidly decreases, indicating the formation of open mitochondrial pores, which increase the levels of the pro-apoptotic protein Bax and reduce the levels of the anti-apoptotic proteins Bcl-2, Bcl-XL, Bcl-Xs, and XIAP. Simultaneously, the open mitochondrial pore leads to the release of cytochrome $\mathrm{c}$ and the activation of caspase-9 and caspase-3. Mitochondrial membrane disruption also results in the release of the apoptosis-inducing factor endonuclease $G$ (Endo $G$ ) via induction of the caspase-independent apoptotic pathway by mitochondria. Noteworthy, Endo G has not been found to translocate into the nuclei. Overall, these results suggest that anticancer agents in leukocyte extract induce apoptosis in HeLa cells via both caspase-dependent and caspase-independent pathways (127). Furthermore, Theansungnoen and colleagues have shown that the peptides
KT2 and RT2, derived from crocodile leukocyte extract, act as death ligands and could upregulate death receptors including TRAIL R2, Fas and TNF RI. Fas-associated death domain is activated by peptide-receptor binding, and pro-caspase- 8 is subsequently cleaved, thus generating caspase-8; high expression levels of pro-caspase- 3 in HeLa cells and activation of the caspase- 8 and caspase- 3 apoptosis pathway have also been observed (Fig. 3) (128).

Aurilide, isolated from the Japanese sea hare, selectively binds to prohibitin 1 (PHB1) in mitochondria. PHB1 localizes in the inner membrane of mitochondria and may activate the proteolytic processing of optic atrophyl (OPA1) and result in mitochondria-induced apoptosis. In detail, aurilide induces prolonged mitochondrial fragmentation by enhancing OPA1 processing, which results in a loss of membrane potential and induces apoptosis (93).

The nonamer peptide LTX-315, derived from bovine lactoferricin, exhibits oncolytic properties. Eike et al have further investigated the oncolytic activity of LTX-315 in human melanoma cells (A375) and have shown that LTX-315 treatment depolarizes the mitochondrial membrane and significantly alters mitochondrial morphology at the ultrastructural level. Simultaneously, death-associated molecular patterns (DAMPs), such as cytochrome-c, ATP, and HMGB1, are released and consequently damage cellular integrity in several ways. Specifically, the release of DAMPs perturb both the cell membrane and mitochondria as shown in Fig. 3 (190). Burns et al have reported a $\mathrm{pH}$-selective peptide (KL AKLAK) analog that inhibits breast cancer cell growth in a dose- and $\mathrm{pH}$-dependent manner. In addition, they have identified pHLIPKLAKLAK as a better modifier because of its low cytotoxicity at physiological $\mathrm{pH}$ levels, chemical stability, high anti-proliferation potency and specific induction of apoptosis at lower $\mathrm{pH}$ levels via mitochondrial membrane disruption (191).

The group of $\mathrm{Su}$ has reported that ACBP extracted from goat spleens induces apoptosis and blocks the cell cycle by decreasing the gene expression levels of cyclin D1, c-myc, and bcl-2 as well as the protein expression of PCNA. It also increases p16Ink4, p21Waf1, p27Kip1 and bax expression (14). Furthermore, in vitro and in vivo findings suggest that PARP, p53, and Mcl-1 mediate ACBP-induced apoptosis. These studies suggest that ACBPs inhibit human colorectal tumor cell growth and induce apoptosis by modulating the PARPp53-Mcl-1 signaling pathway. Further studies are needed to elucidate the role of mitochondrial membrane disruption in this apoptosis cascade (17).

\section{Summary and perspective}

The use of anticancer peptides has become more prevalent for the clinical treatment of cancer. However, in addition to their many advantages these peptides also have drawbacks, such as their lack of oral bioavailability and low stability under physiological conditions; gastric acids and complex enzymes in the gastrointestinal environment make anticancer peptides vulnerable to degradation $(192,193)$. Strategies to develop a selective delivery system have been described $(194,195)$, and these strategies result in highly efficacious treatment. Some cancer-targeting peptides have been designed on the basis of the $\mathrm{pH}$ difference between tumor tissue and normal tissues (196); the peptide selectively 
kills tumor cells at acidic pH levels but is nontoxic against normal cells. Furthermore, owing to their unique optical, electronic, magnetic, photoresponsive, and structural properties, nanotechnology and nanomaterials have provided tremendous potential for application of anticancer peptides in tumor-targeted therapy, bio-imaging, and diagnosis $(197,198)$. Moreover, a new methodology based on dynamic multiple complex views is needed to study the mechanism of action of anticancer bioactive peptides (181). Anticancer peptide-related pharmaceutical research and development are likely to garner significant attention and investment over the next several decades, to integrate their characteristics and fully exploit their potential to benefit thousands of patients who are suffering from cancer.

\section{References}

1. Siegel RL, Miller KD and Jemal A: Cancer statistics, 2015. CA Cancer J Clin 65: 5-29, 2015.

2. McGuire S: World Cancer Report 2014. Geneva, Switzerland: World Health Organization, International Agency for Research on Cancer, WHO Press, 2015. Adv Nutr 7: 418-419, 2016.

3. Peer D, Karp JM, Hong S, Farokhzad OC, Margalit R and Langer R: Nanocarriers as an emerging platform for cancer therapy. Nat Nanotechnol 2: 751-760, 2007.

4. Amit D and Hochberg A: Development of targeted therapy for bladder cancer mediated by a double promoter plasmid expressing diphtheria toxin under the control of $\mathrm{H} 19$ and IGF2-P4 regulatory sequences. J Transl Med 8: 134, 2010.

5. Kang TH, Mao CP, He L, Tsai YC, Liu K, La V, Wu TC and Hung CF: Tumor-targeted delivery of IL-2 by NKG2D leads to accumulation of antigen-specific $\mathrm{CD} 8^{+} \mathrm{T}$ cells in the tumor loci and enhanced anti-tumor effects. PLoS One 7: e35141, 2012.

6. Blaurock N, Schmerler D, Hünniger K, Kurzai O, Ludewig K, Baier M, Brunkhorst FM, Imhof D and Kiehntopf M: C-termina alpha-1 antitrypsin peptide: A new sepsis biomarker with immunomodulatory function. Mediators Inflamm 2016: 6129437, 2016

7. Porta A, Petrone AM, Morello S, Granata I, Rizzo F, Memoli D, Weisz A and Maresca B: Design and expression of peptides with antimicrobial activity against Salmonella typhimurium. Cell Microbiol 19: e12645, 2017. doi: 10.1111/cmi.12645.

8. Dabarera MC, Athiththan LV and Perera RP: Antihypertensive peptides from curd. Ayu 36: 214-219, 2015.

9. Shiratsuchi E, Ura M, Nakaba M, Maeda I and Okamoto K: Elastin peptides prepared from piscine and mammalian elastic tissues inhibit collagen-induced platelet aggregation and stimulate migration and proliferation of human skin fibroblasts. J Pept Sci 16: 652-658, 2010.

10. Qin Y, Zhou J, Zhang W, Yang X, Wang J, Wei C, Gu F and Lei T: Construction of an anticancer fusion peptide (ACFP) derived from milk proteins and an assay of anti-ovarian cancer cells in vitro. Anticancer Agents Med Chem: Jun 26, 2016 (Epub ahead of print)

11. Kongcharoen A, Poolex W, Wichai T and Boonsombat R Production of an antioxidative peptide from hairy basil seed waste by a recombinant Escherichia coli. Biotechnol Lett 38 1195-1201, 2016.

12. Iwaniak A, Darewicz M, Minkiewicz P, Protasiewicz M and Borawska J: (Biologically active peptides derived from food proteins as the food components with cardioprotective properties). Pol Merkur Lekarski 36: 403-406, 2014 (In Polish).

13. Jang A, Jo C, Kang K-S and Lee M: Antimicrobial and human cancer cell cytotoxic effect of synthetic angiotensin-converting enzyme (ACE) inhibitory peptides. Food Chem 107: 327-336, 2008.

14. Su L, Xu G, Shen J, Tuo Y, Zhang X, Jia S, Chen Z and Su X: Anticancer bioactive peptide suppresses human gastric cancer growth through modulation of apoptosis and the cell cycle. Oncol Rep 23: 3-9, 2010.

15. Yu L, Yang L, An W and Su X: Anticancer bioactive peptide-3 inhibits human gastric cancer growth by suppressing gastric cancer stem cells. J Cell Biochem 115: 697-711, 2014.

16. Su X, Dong C, Zhang J, Su L, Wang X, Cui H and Chen Z: Combination therapy of anti-cancer bioactive peptide with Cisplatin decreases chemotherapy dosing and toxicity to improve the quality of life in xenograft nude mice bearing human gastric cancer. Cell Biosci 4: 7, 2014
17. Su LY, Shi YX, Yan MR, Xi Y and Su XL: Anticancer bioactive peptides suppress human colorectal tumor cell growth and induce apoptosis via modulating the PARP-p53-Mcl-1 signaling pathway. Acta Pharmacol Sin 36: 1514-1519, 2015.

18. Park YW and Nam MS: Bioactive peptides in milk and dairy products: A review. Korean J Food Sci Anim Resour 35: 831-840, 2015.

19. Roy MK, Watanabe Y and Tamai Y: Induction of apoptosis in HL-60 cells by skimmed milk digested with a proteolytic enzyme from the yeast Saccharomyces cerevisiae. J Biosci Bioeng 88: 426-432, 1999.

20. Meisel $\mathrm{H}$ and FitzGerald RJ: Biofunctional peptides from milk proteins: Mineral binding and cytomodulatory effects. Curr Pharm Des 9: 1289-1295, 2003.

21. MacDonald RS, Thornton WH Jr and Marshall RT: A cell culture model to identify biologically active peptides generated by bacterial hydrolysis of casein. J Dairy Sci 77: 1167-1175, 1994.

22. Ganjam LS, Thornton WH Jr, Marshall RT and MacDonald RS: Antiproliferative effects of yogurt fractions obtained by membrane dialysis on cultured mammalian intestinal cells. J Dairy Sci 80: 2325-2329, 1997.

23. Legrand D, Pierce A, Elass E, Carpentier M, Mariller C and Mazurier J: Lactoferrin structure and functions. Adv Exp Med Biol 606: 163-194, 2008.

24. Sánchez-Gómez S, Ferrer-Espada R, Stewart PS, Pitts B, Lohner K and Martínez de Tejada G: Antimicrobial activity of synthetic cationic peptides and lipopeptides derived from human lactoferricin against Pseudomonas aeruginosa planktonic cultures and biofilms. BMC Microbiol 15: 137, 2015.

25. Yin C, Wong JH and Ng TB: Recent studies on the antimicrobial peptides lactoferricin and lactoferrampin. Curr Mol Med 14: 1139-1154, 2014.

26. Mader JS, Salsman J, Conrad DM and Hoskin DW: Bovine lactoferricin selectively induces apoptosis in human leukemia and carcinoma cell lines. Mol Cancer Ther 4: 612-624, 2005.

27. Eliassen LT, Berge G, Leknessund A, Wikman M, Lindin I, Løkke C, Ponthan F, Johnsen JI, Sveinbjørnsson B, Kogner P, et al: The antimicrobial peptide, lactoferricin $\mathrm{B}$, is cytotoxic to neuroblastoma cells in vitro and inhibits xenograft growth in vivo. Int J Cancer 119: 493-500, 2006.

28. Yin CM, Wong JH, Xia J and Ng TB: Studies on anticancer activities of lactoferrin and lactoferricin. Curr Protein Pept Sci 14: 492-503, 2013.

29. Harnedy PA and FitzGerald RJ: Bioactive peptides from marine processing waste and shellfish: A review. J Funct Foods 4: 6-24, 2012.

30. Zhou QJ, Wang J, Liu M, Qiao Y, Hong WS, Su YQ, Han KH, Ke QZ and Zheng WQ: Identification, expression and antibacterial activities of an antimicrobial peptide NK-lysin from a marine fish Larimichthys crocea. Fish Shellfish Immunol 55: 195-202, 2016.

31. Shaala LA, Youssef DT, Ibrahim SR and Mohamed GA: Callyptide A, a new cytotoxic peptide from the Red Sea marine sponge Callyspongia species. Nat Prod Res: Mar 7, 2016 (Epub ahead of print).

32. Suarez-Jimenez GM, Burgos-Hernandez A and EzquerraBrauer JM: Bioactive peptides and depsipeptides with anticancer potential: Sources from marine animals. Mar Drugs 10: 963-986, 2012.

33. Guha P, Kaptan E, Bandyopadhyaya G, Kaczanowska S, Davila E, Thompson K, Martin SS, Kalvakolanu DV, Vasta GR and Ahmed $\mathrm{H}$ : Cod glycopeptide with picomolar affinity to galectin-3 suppresses T-cell apoptosis and prostate cancer metastasis. Proc Natl Acad Sci USA 110: 5052-5057, 2013.

34. Jumeri and Kim SM: Antioxidant and anticancer activities of enzymatic hydrolysates of solitary tunicate (Styela clava). Food Sci Biotechnol 20: 1075, 2011.

35. Kurt O, Ozdal-Kurt F, Tuğlu MI and Akçora CM: The cytotoxic, neurotoxic, apoptotic and antiproliferative activities of extracts of some marine algae on the MCF-7 cell line. Biotech Histochem 89: 568-576, 2014.

36. Hsu K-C, Li-Chan ECY and Jao C-L: Antiproliferative activity of peptides prepared from enzymatic hydrolysates of tuna dark muscle on human breast cancer cell line MCF-7. Food Chem 126: 617-622, 2011.

37. Lee YG, Kim JY, Lee KW, Kim KH and Lee HJ: Peptides from anchovy sauce induce apoptosis in a human lymphoma cell (U937) through the increase of caspase-3 and -8 activities. Ann NY Acad Sci 1010: 399-404, 2003. 
38. Lee YG, Lee KW, Kim JY, Kim KH and Lee HJ: Induction of apoptosis in a human lymphoma cell line by hydrophobic peptide fraction separated from anchovy sauce. Biofactors 21: 63-67, 2004.

39. Picot L, Bordenave S, Didelot S, Fruitier-Arnaudin I, Sannier F, Thorkelsson G, Bergé JP, Guérard F, Chabeaud A and Piot JM: Antiproliferative activity of fish protein hydrolysates on human breast cancer cell lines. Process Biochem 41: 1217-1222, 2006.

40. Chen JY, Lin WJ and Lin TL: A fish antimicrobial peptide, tilapia hepcidin TH2-3, shows potent antitumor activity against human fibrosarcoma cells. Peptides 30: 1636-1642, 2009.

41. Chang WT, Pan CY, Rajanbabu V, Cheng CW and Chen JY: Tilapia (Oreochromis mossambicus) antimicrobial peptide, hepcidin $1-5$, shows antitumor activity in cancer cells. Peptides 32: 342-352, 2011.

42. Chen JY, Lin WJ, Wu JL, Her GM and Hui CF: Epinecidin-1 peptide induces apoptosis which enhances antitumor effects in human leukemia U937 cells. Peptides 30: 2365-2373, 2009.

43. Hsu JC, Lin LC, Tzen JT and Chen JY: Characteristics of the antitumor activities in tumor cells and modulation of the inflammatory response in RAW264.7 cells of a novel antimicrobial peptide, chrysophsin-1, from the red sea bream (Chrysophrys major). Peptides 32: 900-910, 2011.

44. Wu SP, Huang TC, Lin CC, Hui CF, Lin CH and Chen JY: Pardaxin, a fish antimicrobial peptide, exhibits antitumor activity toward murine fibrosarcoma in vitro and in vivo. Mar Drugs 10: $1852-1872,2012$

45. Wilson-Sanchez G, Moreno-Félix C, Velazquez C, PlascenciaJatomea M, Acosta A, Machi-Lara L, Aldana-Madrid ML, Ezquerra-Brauer JM, Robles-Zepeda R and BurgosHernandez A: Antimutagenicity and antiproliferative studies of lipidic extracts from white shrimp (Litopenaeus vannamei). Mar Drugs 8: 2795-2809, 2010.

46. Lin MC, Lin SB, Chen JC, Hui CF and Chen JY: Shrimp antilipopolysaccharide factor peptide enhances the antitumor activity of cisplatin in vitro and inhibits HeLa cells growth in nude mice. Peptides 31: 1019-1025, 2010.

47. Somboonwiwat K, Marcos M, Tassanakajon A, Klinbunga S, Aumelas A, Romestand B, Gueguen Y, Boze H, Moulin G and Bachère E: Recombinant expression and anti-microbial activity of anti-lipopolysaccharide factor (ALF) from the black tiger shrimp Penaeus monodon. Dev Comp Immunol 29: 841-851, 2005.

48. Kannan A, Hettiarachchy NS, Marshall M, Raghavan S and Kristinsson H: Shrimp shell peptide hydrolysates inhibit human cancer cell proliferation. J Sci Food Agric 91: 1920-1924, 2011.

49. Aneiros A and Garateix A: Bioactive peptides from marine sources: Pharmacological properties and isolation procedures. J Chromatogr B Analyt Technol Biomed Life Sci 803: 41-53, 2004

50. Baker MA, Grubb DR and Lawen A: Didemnin B induces apoptosis in proliferating but not resting peripheral blood mononuclear cells. Apoptosis 7: 407-412, 2002.

51. Ahuja D, Vera MD, SirDeshpande BV, Morimoto H, Williams PG, Joullié MM and Toogood PL: Inhibition of protein synthesis by didemnin B: How EF-1alpha mediates inhibition of translocation. Biochemistry 39: 4339-4346, 2000.

52. Vera MD and Joullié MM: Natural products as probes of cell biology: 20 years of didemnin research. Med Res Rev 22: 102-145, 2002 .

53. Taraboletti G, Poli M, Dossi R, Manenti L, Borsotti P, Faircloth GT, Broggini M, D'Incalci M, Ribatti D and Giavazzi R: Antiangiogenic activity of aplidine, a new agent of marine origin. Br J Cancer 90: 2418-2424, 2004.

54. Andavan GS and Lemmens-Gruber R: Cyclodepsipeptides from marine sponges: Natural agents for drug research. Mar Drugs 8 : 810-834, 2010.

55. Faivre S, Chièze S, Delbaldo C, Ady-Vago N, Guzman C, LopezLazaro L, Lozahic S, Jimeno J, Pico F, Armand JP, et al: Phase I and pharmacokinetic study of aplidine, a new marine cyclodepsipeptide in patients with advanced malignancies. J Clin Oncol 23: 7871-7880, 2005.

56. Geldof AA, Mastbergen SC, Henrar RE and Faircloth GT: Cytotoxicity and neurocytotoxicity of new marine anticancer agents evaluated using in vitro assays. Cancer Chemother Pharmacol 44: 312-318, 1999.

57. Albella B, Faircloth G, López-Lázaro L, Guzmán C, Jimeno J and Bueren JA: In vitro toxicity of ET-743 and aplidine, two marine-derived antineoplastics, on human bone marrow haematopoietic progenitors. comparison with the clinical results. Eur J Cancer 38: 1395-1404, 2002
58. Hamada Y and Shioiri T: Recent progress of the synthetic studies of biologically active marine cyclic peptides and depsipeptides. Chem Rev 105: 4441-4482, 2005.

59. Vervoort H, Fenical $W$ and Epifanio RA: Tamandarins A and B: New cytotoxic depsipeptides from a Brazilian ascidian of the family Didemnidae. J Org Chem 65: 782-792, 2000.

60. Cheng L, Wang C, Liu H, Wang F, Zheng L, Zhao J, Chu E and Lin X: A novel polypeptide extracted from Ciona savignyi induces apoptosis through a mitochondrial-mediated pathway in human colorectal carcinoma cells. Clin Colorectal Cancer 11: 207-214, 2012.

61. Liu G, Liu M, Wei J, Huang H, Zhang Y, Zhao J, Xiao L, Wu N, Zheng L and Lin X: CS5931, a novel polypeptide in Ciona savignyi, represses angiogenesis via inhibiting vascular endothelial growth factor (VEGF) and matrix metalloproteinases (MMPs). Mar Drugs 12: 1530-1544, 2014

62. Blunt JW, Copp BR, Hu WP, Munro MH, Northcote PT and Prinsep MR: Marine natural products. Nat Prod Rep 26: 170-244, 2009.

63. Ibrahim SR, Min CC, Teuscher F, Ebel R, Kakoschke C, Lin W, Wray V, Edrada-Ebel R and Proksch P: Callyaerins A-F and H, new cytotoxic cyclic peptides from the Indonesian marine sponge Callyspongia aerizusa. Bioorg Med Chem 18: 4947-4956, 2010.

64. Coello L, Reyes F, Martín MJ, Cuevas C and Fernández R: Isolation and structures of pipecolidepsins $\mathrm{A}$ and $\mathrm{B}$, cytotoxic cyclic depsipeptides from the Madagascan sponge Homophymia lamellosa. J Nat Prod 77: 298-303, 2014.

65. Zhan KX, Jiao WH, Yang F, Li J, Wang SP, Li YS, Han BN and Lin HW: Reniochalistatins A-E, cyclic peptides from the marine sponge Reniochalina stalagmitis. J Nat Prod 77: 2678-2684, 2014.

66. Williams DE, Yu K, Behrisch HW, Van Soest R and Andersen RJ: Rolloamides A and B, cytotoxic cyclic heptapeptides isolated from the Caribbean marine sponge Eurypon laughlini. J Nat Prod 72: 1253-1257, 2009.

67. Nakazawa H, Kitano K, Cioca D, Ishikawa M, Ueno M, Ishida F and Kiyosawa K: Induction of polyploidization by jaspamide in HL-60 cells. Acta Haematol 104: 65-71, 2000.

68. Cioca DP and Kitano K: Induction of apoptosis and CD10/neutral endopeptidase expression by jaspamide in HL-60 line cells. Cell Mol Life Sci 59: 1377-1387, 2002.

69. Odaka C, Sanders ML and Crews P: Jasplakinolide induces apoptosis in various transformed cell lines by a caspase-3-like protease-dependent pathway. Clin Diagn Lab Immunol 7: 947-952, 2000

70. Ebada SS, Wray V, de Voogd NJ, Deng Z, Lin W and Proksch P: Two new jaspamide derivatives from the marine sponge Jaspis splendens. Mar Drugs 7: 434-444, 2009.

71. Zampella A, Sepe V, Bellotta F,Luciano P,D'Auria MV, Cresteil T, Debitus C, Petek S, Poupat C and Ahond A: Homophymines B-E and A1-E1, a family of bioactive cyclodepsipeptides from the sponge Homophymia sp. Org Biomol Chem 7: 4037-4044, 2009.

72. Pelay-Gimeno M, García-Ramos Y, Jesús Martin M, Spengler J, Molina-Guijarro JM, Munt S, Francesch AM, Cuevas C, Tulla-Puche J and Albericio F: The first total synthesis of the cyclodepsipeptide pipecolidepsin A. Nat Commun 4: 2352, 2013.

73. Freitas VM, Rangel M, Bisson LF, Jaeger RG and MachadoSantelli GM: The geodiamolide $\mathrm{H}$, derived from Brazilian sponge Geodia corticostylifera, regulates actin cytoskeleton, migration and invasion of breast cancer cells cultured in three-dimensional environment. J Cell Physiol 216: 583-594, 2008.

74. Tan KC, Wakimoto T and Abe I: Lipodiscamides A-C, new cytotoxic lipopeptides from Discodermia kiiensis. Org Lett 16: 3256-3259, 2014

75. Bishara A, Rudi A, Aknin M, Neumann D, Ben-Califa N and Kashman Y: Taumycins A and B, two bioactive lipodepsipeptides from the Madagascar sponge Fascaplysinopsis sp. Org Lett 10: 4307-4309, 2008

76. Teta R, Irollo E, Della Sala G, Pirozzi G, Mangoni A and Costantino V: Smenamides A and B, chlorinated peptide/ polyketide hybrids containing a dolapyrrolidinone unit from the Caribbean sponge Smenospongia aurea. Evaluation of their role as leads in antitumor drug research. Mar Drugs 11: 4451-4463, 2013.

77. Wang YK, He HL, Wang GF, Wu H, Zhou BC, Chen XL and Zhang YZ: Oyster (Crassostrea gigas) hydrolysates produced on a plant scale have antitumor activity and immunostimulating effects in BALB/c mice. Mar Drugs 8: 255-268, 2010. 
78. Cheong SH, Kim EK, Hwang JW, Kim YS, Lee JS, Moon SH, Jeon BT and Park PJ: Purification of a novel peptide derived from a shellfish, Crassostrea gigas, and evaluation of its anticancer property. J Agric Food Chem 61: 11442-11446, 2013.

79. Kim EK, Joung HJ, Kim YS, Hwang JW, Ahn CB, Jeon YJ, Moon SH and Park PJ: Purification of a novel anticancer peptide from enzymatic hydrolysate of Mytilus coruscus. J Microbiol Biotechnol 22: 1381-1387, 2012.

80. Harris JR and Mark1 J: Keyhole limpet hemocyanin: Molecular structure of a potent marine immunoactivator. A review. Eur Urol 37 (Suppl 3): 24-33, 2000.

81. Tzianabos AO: Polysaccharide immunomodulators as therapeutic agents: Structural aspects and biologic function. Clin Microbiol Rev 13: 523-533, 2000.

82. Lamm DL, Dehaven JI and Riggs DR: Keyhole limpet hemocyanin immunotherapy of bladder cancer: Laboratory and clinical studies. Eur Urol 37 (Suppl 3): 41-44, 2000.

83. Murai A, Kitahara K, Okumura S, Kobayashi M and Horio F: Oral antibiotics enhance antibody responses to keyhole limpet hemocyanin in orally but not muscularly immunized chickens. Anim Sci J 87: 257-265, 2016.

84. Riggs DR, Jackson B, Vona-Davis L and McFadden D: In vitro anticancer effects of a novel immunostimulant: Keyhole limpet hemocyanin. J Surg Res 108: 279-284, 2002.

85. McFadden DW, Riggs DR, Jackson BJ and Vona-Davis L: Keyhole limpet hemocyanin, a novel immune stimulant with promising anticancer activity in Barrett's esophageal adenocarcinoma. Am J Surg 186: 552-555, 2003

86. Riggs DR, Jackson BJ, Vona-Davis L, Nigam A and McFadden DW: In vitro effects of keyhole limpet hemocyanin in breast and pancreatic cancer in regards to cell growth, cytokine production, and apoptosis. Am J Surg 189: 680-684, 2005.

87. Pettit GR, Srirangam JK, Barkoczy J, Williams MD, Durkin KP, Boyd MR, Bai R, Hamel E, Schmidt JM and Chapuis JC: Antineoplastic agents 337. Synthesis of dolastatin 10 structural modifications. Anticancer Drug Des 10: 529-544, 1995.

88. Pettit GR, Flahive EJ, Boyd MR, Bai R, Hamel E, Pettit RK and Schmidt JM: Antineoplastic agents 360. Synthesis and cancer cell growth inhibitory studies of dolastatin 15 structural modifications. Anticancer Drug Des 13: 47-66, 1998.

89. Maderna A, Doroski M, Subramanyam C, Porte A, Leverett CA, Vetelino BC, Chen Z, Risley H, Parris K, Pandit J, et al: Discovery of cytotoxic dolastatin 10 analogues with $\mathrm{N}$-terminal modifications. J Med Chem 57: 10527-10543, 2014.

90. Gajula PK, Asthana J, Panda D and Chakraborty TK: A synthetic dolastatin 10 analogue suppresses microtubule dynamics, inhibits cell proliferation, and induces apoptotic cell death. J Med Chem 56: 2235-2245, 2013.

91. Pettit GR, Hogan F and Toms S: Antineoplastic agents. 592 Highly effective cancer cell growth inhibitory structural modifications of dolastatin 10. J Nat Prod 74: 962-968, 2011.

92. Suenaga K, Kajiwara S, Kuribayashi S, Handa T and Kigoshi H: Synthesis and cytotoxicity of aurilide analogs. Bioorg Med Chem Lett 18: 3902-3905, 2008.

93. Sato S, Murata A, Orihara T, Shirakawa T, Suenaga K, Kigoshi H and Uesugi M: Marine natural product aurilide activates the OPA1-mediated apoptosis by binding to prohibitin. Chem Biol 18: 131-139, 2011.

94. Semenzato M, Cogliati S and Scorrano L: Prohibitin(g) cancer: Aurilide and killing by Opa1-dependent cristae remodeling. Chem Biol 18: 8-9, 2011.

95. Shilabin AG and Hamann MT: In vitro and in vivo evaluation of select kahalalide $\mathrm{F}$ analogs with antitumor and antifungal activities. Bioorg Med Chem 19: 6628-6632, 2011.

96. Cruz LJ, Luque-Ortega JR, Rivas L and Albericio F: Kahalalide F, an antitumor depsipeptide in clinical trials, and its analogues as effective antileishmanial agents. Mol Pharm 6: 813-824, 2009.

97. Hosta L, Pla-Roca M, Arbiol J, López-Iglesias C, Samitier J, Cruz LJ, Kogan MJ and Albericio F: Conjugation of Kahalalide F with gold nanoparticles to enhance in vitro antitumoral activity. Bioconjug Chem 20: 138-146, 2009.

98. García-Rocha M, Bonay $\mathrm{P}$ and Avila J: The antitumoral compound Kahalalide F acts on cell lysosomes. Cancer Lett 99: 43-50, 1996.

99. Janmaat ML, Rodriguez JA, Jimeno J, Kruyt FA and Giaccone G: Kahalalide F induces necrosis-like cell death that involves depletion of ErbB3 and inhibition of Akt signaling. Mol Pharmacol 68: 502-510, 2005.
100. Wesson KJ and Hamann MT: Keenamide A, a bioactive cyclic peptide from the marine mollusk Pleurobranchus forskalii. J Nat Prod 59: 629-631, 1996.

101. Conlon JM, Mechkarska M, Lukic ML and Flatt PR: Potential therapeutic applications of multifunctional host-defense peptides from frog skin as anti-cancer, anti-viral, immunomodulatory, and anti-diabetic agents. Peptides 57: 67-77, 2014.

102. Angeletti LR, Agrimi U, Curia C, French D and MarianiCostantini R: Healing rituals and sacred serpents. Lancet 340: 223-225, 1992.

103. Oelkrug C, Hartke $M$ and Schubert A: Mode of action of anticancer peptides (ACPs) from amphibian origin. Anticancer Res 35: 635-643, 2015.

104. Conlon JM, Demandt A, Nielsen PF, Leprince J, Vaudry H and Woodhams DC: The alyteserins: Two families of antimicrobial peptides from the skin secretions of the midwife toad Alytes obstetricans (Alytidae). Peptides 30: 1069-1073, 2009.

105. Conlon JM, Mechkarska M, Prajeep M, Arafat K, Zaric M, Lukic ML and Attoub S: Transformation of the naturally occurring frog skin peptide, alyteserin-2a into a potent, non-toxic anti-cancer agent. Amino Acids 44: 715-723, 2013

106. Conlon JM, Galadari S, Raza H and Condamine E: Design of potent, non-toxic antimicrobial agents based upon the naturally occurring frog skin peptides, ascaphin-8 and peptide XT-7. Chem Biol Drug Des 72: 58-64, 2008.

107. Rozek T, Wegener KL, Bowie JH, Olver IN, Carver JA, Wallace JC and Tyler MJ: The antibiotic and anticancer active aurein peptides from the Australian bell frogs Litoria aurea and Litoria raniformis the solution structure of aurein 1.2. Eur J Biochem 267: 5330-5341, 2000

108. van Zoggel H, Hamma-Kourbali Y, Galanth C, Ladram A, Nicolas P, Courty J, Amiche M and Delbé J: Antitumor and angiostatic peptides from frog skin secretions. Amino Acids 42: 385-395, 2012.

109. Shi D, Hou X, Wang L, Gao Y, Wu D, Xi X, Zhou M, Kwok HF, Duan J, Chen T, et al: Two novel dermaseptin-like antimicrobial peptides with anticancer activities from the skin secretion of Pachymedusa dacnicolor. Toxins (Basel) 8: 8, 2016.

110. Conlon JM, Woodhams DC, Raza H, Coquet L, Leprince J, Jouenne T, Vaudry H and Rollins-Smith LA: Peptides with differential cytolytic activity from skin secretions of the lemur leaf frog Hylomantis lemur (Hylidae: Phyllomedusinae). Toxicon 50: 498-506, 2007.

111. Wan Y, Ma C, Zhou M, Xi X, Li L, Wu D, Wang L, Lin C, Lopez JC, Chen T, et al: Phylloseptin-PBa - A novel broadspectrum antimicrobial peptide from the skin secretion of the peruvian purple-sided leaf frog (Phyllomedusa baltea) which exhibits cancer cell cytotoxicity. Toxins (Basel) 7: 5182-5193, 2015.

112. Ohsaki Y, Gazdar AF, Chen HC and Johnson BE: Antitumor activity of magainin analogues against human lung cancer cell lines. Cancer Res 52: 3534-3538, 1992.

113. Lehmann J, Retz M, Sidhu SS, Suttmann H, Sell M, Paulsen F, Harder J, Unteregger G and Stöckle M: Antitumor activity of the antimicrobial peptide magainin II against bladder cancer cell lines. Eur Urol 50: 141-147, 2006.

114. Baker MA, Maloy WL, Zasloff M and Jacob LS: Anticancer efficacy of Magainin2 and analogue peptides. Cancer Res 53: 3052-3057, 1993.

115. Koszałka P, Kamysz E, Wejda M, Kamysz W and Bigda J: Antitumor activity of antimicrobial peptides against U937 histiocytic cell line. Acta Biochim Pol 58: 111-117, 2011.

116. Miyazaki Y, Aoki M, Yano Y and Matsuzaki K: Interaction of antimicrobial peptide magainin 2 with gangliosides as a target for human cell binding. Biochemistry 51: 10229-10235, 2012.

117. Li S, Hao L, Bao W, Zhang P, Su D, Cheng Y, Nie L, Wang G, Hou F and Yang Y: A novel short anionic antibacterial peptide isolated from the skin of Xenopus laevis with broad antibacterial activity and inhibitory activity against breast cancer cell. Arch Microbiol 198: 473-482, 2016.

118. Libério MS, Joanitti GA, Azevedo RB, Cilli EM, Zanotta LC, Nascimento AC, Sousa MV, Pires Júnior OR, Fontes W and Castro MS: Anti-proliferative and cytotoxic activity of pentadactylin isolated from Leptodactylus labyrinthicus on melanoma cells. Amino Acids 40: 51-59, 2011.

119. Attoub S, Arafat H, Mechkarska M and Conlon JM: Anti-tumor activities of the host-defense peptide hymenochirin-1B. Regul Pept 187: 51-56, 2013. 
120. Attoub S, Mechkarska M, Sonnevend A, Radosavljevic G, Jovanovic I, Lukic ML and Conlon JM: Esculentin-2CHa: A host-defense peptide with differential cytotoxicity against bacteria, erythrocytes and tumor cells. Peptides 39: 95-102, 2013.

121. Merchant ME, Roche C, Elsey RM and Prudhomme J: Antibacterial properties of serum from the American alligator (Alligator mississippiensis). Comp Biochem Physiol B Biochem Mol Biol 136: 505-513, 2003.

122. Merchant ME, Pallansch M, Paulman RL, Wells JB, Nalca A and Ptak R: Antiviral activity of serum from the American alligator (Alligator mississippiensis). Antiviral Res 66: 35-38, 2005

123. Merchant ME, Leger N, Jerkins E, Mills K, Pallansch MB, Paulman RL and Ptak RG: Broad spectrum antimicrobial activity of leukocyte extracts from the American alligator (Alligator mississippiensis). Vet Immunol Immunopathol 110: 221-228, 2006.

124. Merchant ME, Roche CM, Thibodeaux D and Elsey RM: Identification of alternative pathway serum complement activity in the blood of the American alligator (Alligator mississippiensis). Comp Biochem Physiol B Biochem Mol Biol 141: 281-288, 2005.

125. Pata S, Yaraksa N, Daduang S, Temsiripong Y, Svasti J, Araki T and Thammasirirak S: Characterization of the novel antibacterial peptide Leucrocin from crocodile (Crocodylus siamensis) white blood cell extracts. Dev Comp Immunol 35: 545-553, 2011.

126. Yaraksa N, Anunthawan T, Theansungnoen T, Daduang S, Araki T, Dhiravisit A and Thammasirirak S: Design and synthesis of cationic antibacterial peptide based on Leucrocin I sequence, antibacterial peptide from crocodile (Crocodylus siamensis) white blood cell extracts. J Antibiot (Tokyo) 67: 205-212, 2014.

127.Patathananone S, Thammasirirak S, Daduang J, Chung JG, Temsiripong Y and Daduang S: Bioactive compounds from crocodile (Crocodylus siamensis) white blood cells induced apoptotic cell death in hela cells. Environ Toxicol 31: 986-997, 2016.

128. Theansungnoen T, Maijaroen S, Jangpromma N, Yaraksa N, Daduang S, Temsiripong T, Daduang J and Klaynongsruang S: Cationic antimicrobial peptides derived from Crocodylus siamensis leukocyte extract, revealing anticancer activity and apoptotic induction on human cervical cancer cells. Protein J 35: 202-211, 2016.

129. He S, Mao X, Zhang T, Guo X, Ge Y, Ma C and Zhang X: Separation and nanoencapsulation of antitumor peptides from Chinese three-striped box turtle (Cuora trifasciata). J Microencapsul 33: 344-354, 2016

130. Chippaux JP and Goyffon M: Epidemiology of scorpionism: A global appraisal. Acta Trop 107: 71-79, 2008.

131. Goudet C, Chi CW and Tytgat J: An overview of toxins and genes from the venom of the Asian scorpion Buthus martensi Karsch. Toxicon 40: 1239-1258, 2002.

132. Srinivasan KN, Gopalakrishnakone P, Tan PT, Chew KC, Cheng B, Kini RM, Koh JL, Seah SH and Brusic V: SCORPION, a molecular database of scorpion toxins. Toxicon 40: 23-31, 2002.

133.DeBin JA, Maggio JE and Strichartz GR: Purification and characterization of chlorotoxin, a chloride channel ligand from the venom of the scorpion. Am J Physiol 264: C361-C369, 1993.

134. Dardevet L, Rani D, Aziz TA, Bazin I, Sabatier JM, Fadl M, Brambilla E and De Waard M: Chlorotoxin: A helpful natural scorpion peptide to diagnose glioma and fight tumor invasion. Toxins (Basel) 7: 1079-1101, 2015.

135. Mamelak AN and Jacoby DB: Targeted delivery of antitumoral therapy to glioma and other malignancies with synthetic chlorotoxin (TM-601). Expert Opin Drug Deliv 4: 175-186, 2007.

136. Veiseh O, Gunn JW, Kievit FM, Sun C, Fang C, Lee JS and Zhang M: Inhibition of tumor-cell invasion with chlorotoxinbound superparamagnetic nanoparticles. Small 5: 256-264, 2009.

137. Deshane J, Garner CC and Sontheimer H: Chlorotoxin inhibits glioma cell invasion via matrix metalloproteinase-2. J Biol Chem 278: 4135-4144, 2003

138. Soroceanu L, Manning TJ Jr and Sontheimer H: Modulation of glioma cell migration and invasion using $\mathrm{Cl}(-)$ and $\mathrm{K}(+)$ ion channel blockers. J Neurosci 19: 5942-5954, 1999.

139. Sontheimer H: An unexpected role for ion channels in brain tumor metastasis. Exp Biol Med (Maywood) 233: 779-791, 2008.
140. Lui VC, Lung SS, Pu JK, Hung KN and Leung GK: Invasion of human glioma cells is regulated by multiple chloride channels including ClC-3. Anticancer Res 30: 4515-4524, 2010.

141. Guo X, Ma C, Du Q, Wei R, Wang L, Zhou M, Chen T and Shaw C: Two peptides, TsAP-1 and TsAP-2, from the venom of the Brazilian yellow scorpion, Tityus serrulatus: Evaluation of their antimicrobial and anticancer activities. Biochimie 95: 1784-1794, 2013.

142. Ali SA, Alam M, Abbasi A, Undheim EA, Fry BG, Kalbacher H and Voelter W: Structure-activity relationship of chlorotoxinlike peptides. Toxins (Basel) 8: 36, 2016.

143. Kuhn-Nentwig L: Antimicrobial and cytolytic peptides of venomous arthropods. Cell Mol Life Sci 60: 2651-2668, 2003.

144. Vorontsova OV, Egorova NS, Arseniev AS and Feofanov AV: Haemolytic and cytotoxic action of latarcin Ltc2a. Biochimie 93: 227-241, 2011

145.Liu Z, Deng M, Xiang J, Ma H, Hu W, Zhao Y, Li DW and Liang S: A novel spider peptide toxin suppresses tumor growth through dual signaling pathways. Curr Mol Med 12: 1350-1360, 2012.

146. Moreno $M$ and Giralt E: Three valuable peptides from bee and wasp venoms for therapeutic and biotechnological use: Melittin, apamin and mastoparan. Toxins (Basel) 7: 1126-1150, 2015.

147. Havas LJ: Effect of bee venom on colchicine-induced tumours. Nature 166: 567-568, 1950

148. Jo M, Park MH, Kollipara PS, An BJ, Song HS, Han SB, Kim JH, Song MJ and Hong JT: Anti-cancer effect of bee venom toxin and melittin in ovarian cancer cells through induction of death receptors and inhibition of JAK2/STAT3 pathway. Toxicol Appl Pharmacol 258: 72-81, 2012.

149. Wang C, Chen T, Zhang N, Yang M, Li B, Lü X, Cao X and Ling C: Melittin, a major component of bee venom, sensitizes human hepatocellular carcinoma cells to tumor necrosis factor-related apoptosis-inducing ligand (TRAIL)-induced apoptosis by activating CaMKII-TAK1-JNK/p38 and inhibiting IkappaBalpha kinase-NFkappaB. J Biol Chem 284: 3804-3813, 2009.

150. Park MH, Choi MS, Kwak DH, Oh KW, Yoon DY, Han SB, Song HS, Song MJ and Hong JT: Anti-cancer effect of bee venom in prostate cancer cells through activation of caspase pathway via inactivation of NF- $\kappa B$. Prostate 71: 801-812, 2011.

151. Park JH, Jeong YJ, Park KK, Cho HJ, Chung IK, Min KS, Kim M, Lee KG, Yeo JH, Park KK, et al: Melittin suppresses PMA-induced tumor cell invasion by inhibiting NF-kappaB and AP-1-dependent MMP-9 expression. Mol Cells 29: 209-215, 2010.

152. Gajski G and Garaj-Vrhovac V: Melittin: A lytic peptide with anticancer properties. Environ Toxicol Pharmacol 36: 697-705, 2013.

153. Pan H, Soman NR, Schlesinger PH, Lanza GM and Wickline SA: Cytolytic peptide nanoparticles ('NanoBees') for cancer therapy. Wiley Interdiscip Rev Nanomed Nanobiotechnol 3: 318-327, 2011.

154. Soman NR, Baldwin SL, Hu G, Marsh JN, Lanza GM, Heuser JE, Arbeit JM, Wickline SA and Schlesinger PH: Molecularly targeted nanocarriers deliver the cytolytic peptide melittin specifically to tumor cells in mice, reducing tumor growth. J Clin Invest 119: 2830-2842, 2009.

155. Yamada Y, Shinohara Y, Kakudo T, Chaki S, Futaki S, Kamiya H and Harashima $\mathrm{H}$ : Mitochondrial delivery of mastoparan with transferrin liposomes equipped with a $\mathrm{pH}$-sensitive fusogenic peptide for selective cancer therapy. Int J Pharm 303: 1-7, 2005.

156. de Azevedo RA, Figueiredo CR, Ferreira AK, Matsuo AL, Massaoka MH, Girola N, Auada AV, Farias CF, Pasqualoto KF, Rodrigues CP, et al: Mastoparan induces apoptosis in B16F10-Nex2 melanoma cells via the intrinsic mitochondrial pathway and displays antitumor activity in vivo. Peptides 68: $113-119,2015$

157. Vyas VK, Brahmbhatt K, Bhatt $\mathrm{H}$ and Parmar U: Therapeutic potential of snake venom in cancer therapy: Current perspectives. Asian Pac J Trop Biomed 3: 156-162, 2013.

158. Kerkis I, Hayashi MA, Prieto da Silva AR, Pereira A, De Sá Júnior PL, Zaharenko AJ, Rádis-Baptista G, Kerkis A and Yamane T: State of the art in the studies on crotamine, a cell penetrating peptide from South American rattlesnake. Biomed Res Int 2014: 675985, 2014.

159. Pereira A, Kerkis A, Hayashi MA, Pereira AS, Silva FS, Oliveira EB, Prieto da Silva AR, Yamane T, Rádis-Baptista G and Kerkis I: Crotamine toxicity and efficacy in mouse models of melanoma. Expert Opin Investig Drugs 20: 1189-1200, 2011. 
160.León G, Sánchez L, Hernández A, Villalta M, Herrera M, Segura A, Estrada R and Gutiérrez JM: Immune response towards snake venoms. Inflamm Allergy Drug Targets 10: 381-398, 2011

161. Wang H, Ke M, Tian Y, Wang J, Li B, Wang Y, Dou J and Zhou C: BF-30 selectively inhibits melanoma cell proliferation via cytoplasmic membrane permeabilization and DNA-binding in vitro and in B16F10-bearing mice. Eur J Pharmacol 707: 1-10, 2013.

162. Naumann GB, Silva LF, Silva L, Faria G, Richardson M, Evangelista K, Kohlhoff M, Gontijo CM, Navdaev A, de Rezende FF, et al: Cytotoxicity and inhibition of platele aggregation caused by an 1-amino acid oxidase from Bothrops leucurus venom. Biochim Biophys Acta 1810: 683-694, 2011.

163. Harris F, Dennison SR, Singh J and Phoenix DA: On the selectivity and efficacy of defense peptides with respect to cancer cells. Med Res Rev 33: 190-234, 2013.

164.Lohner K and Hilpert K: Antimicrobial peptides: Cell membrane and microbial surface interactions. Biochim Biophys Acta 1858 915-917, 2016

165. Bailly C: Anticancer properties of lamellarins. Mar Drugs 13 1105-1123, 2015.

166. Riedl S, Leber R, Rinner B, Schaider H, Lohner K and Zweytick D: Human lactoferricin derived di-peptides deploying loop structures induce apoptosis specifically in cancer cells through targeting membranous phosphatidylserine. Biochim Biophys Acta 1848: 2918-2931, 2015.

167. Riedl S, Rinner B, Asslaber M, Schaider H, Walzer S, Novak A, Lohner K and Zweytick D: In search of a novel target - phosphatidylserine exposed by non-apoptotic tumor cells and metastases of malignancies with poor treatment efficacy. Biochim Biophys Acta 1808: 2638-2645, 2011.

168.Papo N, Seger D, Makovitzki A, Kalchenko V, Eshhar Z, Degani $\mathrm{H}$ and Shai $\mathrm{Y}$ : Inhibition of tumor growth and elimination of multiple metastases in human prostate and breast xenografts by systemic inoculation of a host defense-like lytic peptide. Cancer Res 66: 5371-5378, 2006.

169. Won A, Ruscito A and Ianoul A: Imaging the membrane lytic activity of bioactive peptide latarcin 2a. Biochim Biophys Acta 1818: 3072-3080, 2012.

170.Rashid R, Veleba M and Kline KA: Focal targeting of the bacterial envelope by antimicrobial peptides. Front Cell Dev Biol 4: 55,2016.

171. Sorochkina AI, Kovalchuk SI, Omarova EO, Sobko AA Kotova EA and Antonenko YN: Peptide-induced membrane leakage by lysine derivatives of gramicidin A in liposomes, planar bilayers, and erythrocytes. Biochim Biophys Acta 1828: 2428-2435, 2013.

172. Ryan L, Lamarre B, Diu T, Ravi J, Judge PJ, Temple A, Carr M, Cerasoli E, Su B, Jenkinson HF, et al: Anti-antimicrobia peptides: Folding-mediated host defense antagonists. J Biol Chem 288: 20162-20172, 2013.

173. Han Y, Cui Z, Li YH, Hsu WH and Lee BH: In vitro and in vivo anticancer activity of pardaxin against proliferation and growth of oral squamous cell carcinoma. Mar Drugs 14: 2, 2015.

174. Pino-Angeles A, Leveritt JM III and Lazaridis T: Pore structure and synergy in antimicrobial peptides of the magainin family. PLOS Comput Biol 12: e1004570, 2016.

175.Zhang SK, Song JW, Gong F, Li SB, Chang HY, Xie HM, Gao HW, Tan YX and Ji SP: Design of an $\alpha$-helical antimicrobia peptide with improved cell-selective and potent anti-biofilm activity. Sci Rep 6: 27394, 2016

176. Kashiwada A, Mizuno M and Hashimoto J: pH-Dependent membrane lysis by using melittin-inspired designed peptides. Org Biomol Chem 14: 6281-6288, 2016.

177. Ros U and García-Sáez AJ: More Than a Pore: The interplay of pore-forming proteins and lipid membranes. J Membr Biol 248 545-561, 2015 .

178. Bolintineanu DS, Vivcharuk V and Kaznessis YN: Multiscale models of the antimicrobial peptide protegrin-1 on gramnegative bacteria membranes. Int J Mol Sci 13: 11000-11011, 2012.
179. Lohner K: Novel antibiotics based upon the multiple mechanisms of membrane perturbation by antimicrobial peptides. Curr Top Med Chem July 2016 (In press).

180. Wang C, Zolotarskaya OY, Nair SS, Ehrhardt CJ, Ohman DE, Wynne KJ and Yadavalli VK: Real-time observation of antimicrobial polycation effects on Escherichia coli: Adapting the carpet model for membrane disruption to quaternary copolyoxetanes. Langmuir 32: 2975-2984, 2016.

181. Bechinger B: The SMART model: Soft membranes adapt and respond, also transiently, in the presence of antimicrobial peptides. J Pept Sci 21: 346-355, 2015.

182. Mulder KC, Lima LA, Miranda VJ, Dias SC and Franco OL: Current scenario of peptide-based drugs: The key roles of cationic antitumor and antiviral peptides. Front Microbiol 4: $321,2013$.

183. Whelan RS, Konstantinidis K, Wei AC, Chen Y, Reyna DE, Jha S, Yang Y, Calvert JW, Lindsten T, Thompson CB, et al: Bax regulates primary necrosis through mitochondrial dynamics. Proc Natl Acad Sci USA 109: 6566-6571, 2012.

184.Linkermann A, Konstantinidis K and Kitsis RN: Catch me if you can: Targeting the mitochondrial permeability transition pore in myocardial infarction. Cell Death Differ 23: 1-2, 2016.

185. Karch J, Kwong JQ, Burr AR, Sargent MA, Elrod JW, Peixoto PM, Martinez-Caballero S, Osinska H, Cheng EH, Robbins J, et al: Bax and Bak function as the outer membrane component of the mitochondrial permeability pore in regulating necrotic cell death in mice. eLife 2: e00772, 2013.

186. Farsinejad S, Gheisary Z, Ebrahimi Samani S and Alizadeh AM: Mitochondrial targeted peptides for cancer therapy. Tumour Biol 36: 5715-5725, 2015 .

187. Meng MX, Ning JF, Yu JY, Chen DD, Meng XL, Xu JP and Zhang J: Antitumor activity of recombinant antimicrobial peptide penaeidin-2 against kidney cancer cells. J Huazhong Univ Sci Technolog Med Sci 34: 529-534, 2014.

188. Hilchie AL, Doucette CD, Pinto DM, Patrzykat A, Douglas S and Hoskin DW: Pleurocidin-family cationic antimicrobial peptides are cytolytic for breast carcinoma cells and prevent growth of tumor xenografts. Breast Cancer Res 13: R102, 2011.

189. Hilchie AL, Conrad DM, Coombs MR, Zemlak T, Doucette CD, Liwski RS and Hoskin DW: Pleurocidin-family cationic antimicrobial peptides mediate lysis of multiple myeloma cells and impair the growth of multiple myeloma xenografts. Leuk Lymphoma 54: 2255-2262, 2013.

190.Eike LM, Yang N, Rekdal Ø and Sveinbjørnsson B: The oncolytic peptide LTX-315 induces cell death and DAMP release by mitochondria distortion in human melanoma cells. Oncotarget 6: 34910-34923, 2015.

191. Burns KE, McCleerey TP and Thévenin D: pH-Selective Cytotoxicity of pHLIP-Antimicrobial Peptide Conjugates. Sci Rep 6: 28465, 2016

192. Mandal SM, Pati BR, Chakraborty R and Franco OL: New insights into the bioactivity of peptides from probiotics. Front Biosci (Elite Ed) 8: 450-459, 2016.

193. Gaspar D, Veiga AS and Castanho MA: From antimicrobial to anticancer peptides. A review. Front Microbiol 4: 294, 2013

194.Liao W, Zhang R, Dong C, Yu Z and Ren J: Novel walnut peptide-selenium hybrids with enhanced anticancer synergism: Facile synthesis and mechanistic investigation of anticancer activity. Int J Nanomed 11: 1305-1321, 2016.

195. Svensen N, Walton JG and Bradley M: Peptides for cell-selective drug delivery. Trends Pharmacol Sci 33: 186-192, 2012.

196. Wakabayashi N, Yano Y, Kawano K and Matsuzaki K: A $\mathrm{pH}$-dependent charge reversal peptide for cancer targeting. Eur Biophys J 46: 121-127, 2017.

197. Hu X and Liu S: Recent advances towards the fabrication and biomedical applications of responsive polymeric assemblies and nanoparticle hybrid superstructures. Dalton Trans 44: 3904-3922, 2015.

198. Balducci A, Wen Y, Zhang Y, Helfer BM, Hitchens TK, Meng WS, Wesa AK and Janjic JM: A novel probe for the non-invasive detection of tumor-associated inflammation. OncoImmunology 2: e23034, 2013. 